\title{
Impact of Drilling Activities in Warm Sea: Recolonization Capacities of Seabed
}

\author{
Ch. Dalmazzone', D. Blanchet ${ }^{1}$, S. Lamoureux², E. Dutrieux², J. Durrieu², \\ R. Camps $^{3}$ and F. Galgani ${ }^{4}$ \\ 1 Institut français du pétrole, 1 et 4, avenue Bois-Préau, 92852 Rueil-Malmaison Cedex - France \\ 2 CréOcéan, 740, avenue des Apothicaires, 34000 Montpellier - France \\ 3 Total, avenue Larribau, 64018 Pau - France \\ 4 Ifremer, avenue J.-Monnet, 34203 Sète - France \\ e-mail: christine.dalmazzone@ifp.fr - denis.blanchet@ifp.fr - canovas@creocean.fr -dutrieux@creocean.fr \\ josiane.durrieu@total.com - roger.camps@total.com - francois.galgani@ifremer.fr
}

Résumé - Impact des activités de forage en mer chaude : capacités de recolonisation des fonds marins - Étant donné les contraintes importantes liées aux réglementations environnementales, le rejet des déblais de forage en mer doit être contrôlé. Il est par conséquent nécessaire de recueillir des informations afin de contribuer à la sélection de fluides de forage respectueux de l'environnement. Cette étude a été menée dans l'objectif d'évaluer, dans les conditions les plus réalistes possible, l'impact des déblais de forage, la capacité de régénération des écosystèmes et les processus de recolonisation. Dans une première phase, différents tests ont été réalisés sur plusieurs sortes de boues de forage et de déblais (contenant du gazole, deux huiles paraffiniques différentes et du glycol) : des tests de toxicité standards (OSPAR) et expérimentaux, des mesures de biodégradation en conditions aérobie et anaérobie, et des tests de lixiviation. Dans une seconde phase, les mesures les plus appropriées ont été appliquées dans le cadre d'une expérience sur un site de rejet de déblais au Congo (Afrique). Les opérations de rejet ont débuté en novembre 1993 et ont pris fin en avril 1999. Parallèlement à cette campagne de mesures, une analyse complète du benthos a été réalisée huit ans après le début des rejets. Les résultats préliminaires ont démontré que :

- la zone de toxicité provoquant des modifications du benthos est inférieure à quelques centaines de mètres autour du site de rejet ;

- la faune originale a été remplacée par une faune plus spécifique.

Dans le contexte plus général des contraintes environnementales liées à l'industrie pétrolière, ce travail a démontré le confinement des zones d'impact, l'absence de risques significatifs de modification des écosystèmes adjacents ainsi que l'application possible à d'autres sites de rejet de déblais.

\footnotetext{
Abstract - Impact of Drilling Activities in Warm Sea: Recolonization Capacities of Seabed - Due to large constraints in environmental regulations, discharge of drill cuttings at sea has to be controlled. It is therefore necessary to get basic information in order to select environment-friendly drilling fluids. The present study was intended to assess the impact of cuttings, the capacity of regeneration of the ecosystem and the processes of recolonization of seabeds. In a first phase, standardized (OSPAR) and experimental toxicity tests, aerobic and anaerobic degradation measurements and lixiviation tests were performed on various types of muds and cuttings (containing diesel oil, two different paraffinic oils, and glycol) in laboratory conditions.
} 
In a second phase, the most suitable measurements were taken within the framework of an in situ experiment at a discharge site in Congo (Africa). Cuttings discharge began in November 1993 and ended in April 1999. Together with this survey, a complete analysis of benthos was performed eight years after the beginning of cuttings discharge. The preliminary results demonstrated:

- the zone of extension of the toxicity inducing benthos modifications was less than a few hundred meters around the discharge site;

- original fauna was replaced by a more specific fauna.

In the more general context of the environmental constraints in the oil industry, our work demonstrated the containment of the impacted zones, the absence of significant risks of modification of the adjacent ecosystems and the possible application to other discharge sites.

\section{ACRONYMS}

\begin{tabular}{|c|c|}
\hline BTEX & Benzene, Toluene, Ethylbenzene, Xylenes \\
\hline $\mathrm{EC}_{50}$ & $\begin{array}{l}\text { Effective concentration that causes } 50 \% \text { of } \\
\text { anomalies }\end{array}$ \\
\hline GC & Gas Chromatography \\
\hline $\mathrm{HC}$ & Hydrocarbons \\
\hline IR & Infrared \\
\hline $\mathrm{LC}_{50}$ & $\begin{array}{l}\text { Lethal concentration that affects } 50 \% \text { of a test } \\
\text { population }\end{array}$ \\
\hline
\end{tabular}

$\begin{array}{ll}\text { LTMBF } & \text { Low Toxicity Mineral Oil Base Fluid } \\ \text { NABF } & \text { Non Aqueous Base Fluid } \\ \text { NADF } & \text { Non Aqueous Drilling Fluid } \\ \text { OBF } & \text { Oil Base Fluid } \\ \text { OBM } & \text { Oil Base Mud }\end{array}$

PAH Polycyclic Aromatic Hydrocarbons

SBF Synthetic Base Fluid

SBM Synthetic Base Mud

SPME Solid Phase Micro-Extraction

TOC Total Organic Carbon

WBF Water Base Fluid

WBM Water Base Mud

API American Petroleum Institute

EPA Environmental Protection Agency

$E \& P$ Forum ancient name of $O G P$

NIVA Norwegian Institute for Water Research

OGP International Association of Oil \& Gas Producers

OSPAR Convention for the Protection of the Marine Environment of the North-East Atlantic

SOAEFD Scottish Office of Agriculture, Environment and Fisheries Department.

\section{INTRODUCTION}

Drilling operations generate waste fluids and cuttings. Drill cuttings are small pieces of rocks created during the drilling of a well. They are carried back to the surface by the drilling fluid or drilling "mud", that is used to lubricate and cool the drill bit, and to maintain pressure in the well to prevent blow-outs of gas and oil. At the rig, cuttings are separated from mud by several physical means (shale shakers, hydrocyclones, etc.). Then, mud is recycled and cuttings are discharged into the seabed. In the case of oil base muds, depending on the local regulations, cuttings are discharged to the sea, shipped to shore for treatment or reinjected into wells. An accumulation of cuttings material may then occur at the place of discharge, and may give birth to "cutting piles".

Over the past 40 years in the United Kingdom and Norwegian sectors of the North Sea, about $1.3 \mathrm{Mm}^{3}$ of drill cuttings and associated wastes have been built up on the seabed in 102 individual cutting piles with an estimated mass of from 2 to $2.5 \mathrm{Mt}$. The largest pile contains over $66000 \mathrm{~m}^{3}$ of material and weighs about $100000 \mathrm{t}$.

Since the onset of offshore drilling, the drill cuttings and their disposal have received much attention in the oil and gas industry. Numerous studies carried out at laboratory scale on the fate of cuttings have led to new formulations with increased biodegradability and lower toxicity.

Although the study of the impact associated with the discharge of drill cuttings impregnated with fluid has already given rise to numerous works related to the North Sea (UKOOA, 2001), it is clear that knowledge is still limited. Field studies have been done to determine deposition of cuttings on the seabed. But further information is required on the monitoring of cuttings discharged today and on the fate of old cuttings, especially in warm sea conditions.

In order to study the modes of regeneration of the benthic fauna and of recolonization of the seabed after discharge of cuttings, a project was conducted between 2000 and 2002 by Ifremer, Total, IFP and CréOcéan focused on:

- the definition of parameters and their validation as a basis for studying the environmental impact of drill cuttings discharge on the seafloor;

- and the recolonization by the benthic fauna.

The main objectives of this project were:

- to validate an experimental protocol for monitoring recolonization;

- to assess the real impact of cuttings contaminated by oil based drilling fluids; 
- to assess the regeneration capacity of the environment in relation to the amounts of contaminating material.

This project was performed in two steps. The first phase was dedicated to the study of four types of drilling fluids and cuttings from an eco-toxicological point of view (chemical analysis of hydrocarbons, aquatic and sediment toxicity, aerobic and anaerobic biodegradation, lixiviation). The second phase concerned the study of the impact of drill cuttings piles on a real site of discharge (Congo, Africa). Cuttings discharge (essentially low toxicity mineral oil based fluid cuttings) began in November 1993 and ended in April 1999. Previous sampling and analyses were performed in 1995 (after the first step of drilling) and 2000 (one year and a half after the stop of cuttings discharge). In 2002, a systematic study of the abundance and the diversity of the benthic fauna as well as classical physical chemical analyses on the sediment were performed at different distances from the discharge point at the bottom of the platform. In addition, all the methodology previously tested in the first phase (toxicity, biodegradability, lixiviation) was applied to the analysis of these actual cuttings, in order to explain the evolution of the recolonization by the benthic fauna. This survey was specifically applied to an offshore Africa area (Congo). The site was located some $60 \mathrm{~km}$ off Pointe Noire, under a water depth of $180 \mathrm{~m}$. This study concerns warm sea conditions and results will be latter compared to previous studies in temperate and cold seas (Fechelm et al., 1999).

\section{BACKGROUND}

After a brief presentation of the different drilling fluids that are used in offshore drilling operations, this chapter will address the main environmental aspects relating to the fate and effects of marine discharge of cuttings coated with non aqueous drilling fluids. Then, the laboratory testing and field studies that allow the assessment of drill cuttings impact in the marine environment will be presented.

\subsection{Drilling Fluids}

Two types of drilling fluids are generally used: water based fluids (WBFs) and non aqueous drilling fluids (NADFs).

WBFs consist of water mixed with bentonite clay (viscosifier and fluid loss reducer), barium sulphate (barite) to control mud density and other additives like thinners (lignosulphonate, anionic polymers, etc.), filtration control agents (polymers such as carboxymethyl cellulose or starch) and lubrication agents (polyglycols).

NADFs are emulsions where the continuous phase is a base oil with water as the internal phase. Oleophilic additives are also used to control the properties of NADFs i.e. emulsifiers for emulsion stability, organophilic clay for rheological and cake properties, barite for density adjustment, polymers as fluid loss reducers, etc. The base oils used in NADFs can be classified according to their aromatic hydrocarbon concentrations, which contribute to fluid toxicity, as follows:

- oil based fluids (OBF): diesel oil based fluids and conventional mineral oil based fluids with high aromatic content;

- low toxicity mineral oil based fluids (LTMBF): total aromatic hydrocarbon concentrations between 0.5 and 5\% and PAH (polycyclic aromatic hydrocarbons) content between $0.001 \%$ and $0.35 \%$;

- synthetic based fluids (SBF): synthetic hydrocarbons (esters, polymerized olefins and synthetic paraffins) or highly processed mineral oils with PAH content less than $0.001 \%$.

\subsection{Overview of Fate and Effects of Sediments Contaminated by Drill Cuttings Discharge}

Fate and effects of discharged cuttings depend on many factors. First, initial deposition is largely dependent on water depth, currents, as well as volume and density of cuttings. Persistence on the seabed can be related to sediment transport and resuspension as well as biodegradation of the base fluid. The environmental impact of cutting piles can be partly attributed to the "recovering" effect which can destroy the indigenous fauna even in absence of any toxicity. This recovering effect is common to all types of cuttings. On the other hand the main impact is related to the ecotoxicity properties of the non aqueous drilling fluid (base oil) that impregnates the drill cuttings. These ecotoxicity properties are considered through biodegradability (or persistence), toxicity towards reference species, and bioaccumulation. Moreover, the introduction of large quantities of potentially degradable hydrocarbons can lead to drastic depletion of oxygen in the vicinity of the cuttings pile, with tragic effect on the macro and meio fauna. Lastly, the input of organic matter (hydrocarbons) governs the whole recolonization process.

It is noteworthy that organic compounds in the sediment (base oil, settled biomass, etc.) are biodegraded by indigenous microorganisms. As oxygen is present in seawater, aerobic conditions prevail at the exposed surface of the cuttings. When the biodegradation rate in sediments becomes higher than the diffusion rate of oxygen into the sediment, anoxic conditions prevail. If anoxic conditions are generated, additional anaerobic biodegradation by specific populations of microorganisms may occur. When anoxia prevails, benthic organisms (macro and meio fauna) that require oxygen are not able to compete with bacteria for oxygen. Consequently, the rapid biodegradation of the base oil may cause indirectly sediment toxicity.

Chemical toxicity of the components of the NADF can lead to benthic impacts. Generally, the impacts to the water column are reduced due to rapid dilution and low solubility. Major impacts are observed in the benthic communities. 
Unfortunately, it is particularly difficult to distinguish the effects of chemical toxicity from those of anoxia presented above (Jensen et al., 1999).

Bioaccumulation of NADF's components can also lead to benthic impacts. The potential for bioaccumulation of base oils in aquatic species is believed to be low. But bioaccumulation of base oils in benthic species occurs when organisms incorporate hydrocarbons within their biomass, without the ability to depurate or metabolize them. An associated effect is taint, which consists in an alteration of the odor or taste of edible tissues resulting from the uptake of certain substances, including certain hydrocarbons. But there is no evidence that base oils cause taint at the concentrations of discharge (Davies et al., 1989).

Typically, the impacted areas are gradually recolonized over the long term by biological communities. Initial colonization concerns species that are tolerant to hydrocarbons and opportunistic species that feed on bacteria which metabolize hydrocarbons. When hydrocarbons concentrations decrease with time, other species reappear and the communities return to a state quite similar to the initial one.

Deep water benthic communities are not as well known as shallow water communities. They tend to be characterized by a low abundance and a high diversity. Several deepwater studies are underway in different water depths in order to understand the impacts of NADFs on deepwater environments (British Petroleum, 2000, and BioZaire survey by Total/Ifremer).

The complicated combination between physical burial, drilling fluid's toxicity and biodegradability makes the prediction of cuttings piles fate and effects particularly difficult. Laboratory testing and field studies have been undertaken to tentatively assess the real impact of cuttings and the capacity for regeneration of the environment.

\subsection{Laboratory Testing}

Laboratory tests are useful tools to assess the biodegradability, toxicity and potential for bioaccumulation of base oils. However, they are not always predictive of ecological impacts because they do not take into account the complexities and variables of the marine environment.

The Harmonized Mandatory Control System (OSPAR, 2000) for the North Sea and the USEPA's effluent discharge permits in the United States require several laboratory tests in order to determine if a material can be discharged offshore. An exhaustive presentation of these various tests can be found elsewhere (OGP, 2003).

\subsubsection{Biodegradability}

Standard laboratory biodegradation tests in marine water are OECD 306 and marine BODIS (aerobic conditions) and "ISO 11734" (anaerobic conditions). It is noteworthy that the
American Petroleum Institute (API) developed the "modified ISO 11734" test for synthetic fluids and this was accepted by the EPA as a method for complying with the biodegradation guidelines. Compared to "ISO 11734", the test uses naturally occurring microorganisms in sediments as inoculum source, instead of sewage sludge. The SOAEFD test (or Solid Phase Test) was originally developed at the Scottish Office of Agriculture, Environment and Fisheries Department (Munro et al., 1997) in order to determine relative degradation rates of base oils (NABFs) present in large static cutting piles. Finally, other laboratory methods have been developed to study biodegradability of NABFs under simulated North Sea seabed conditions. Most are based on variants of the NIVA test (Norwegian Institute for Water Research).

\subsubsection{Toxicity}

Since base oils (NABFs) show low water solubility and are only present in the water column for a short time after discharge, it is now widely admitted that water column toxicity testing is not representative of the environmental risks associated with cuttings discharge. It seems that sediment toxicity tests are much more relevant. Sediment toxicity tests are performed on sediment dwelling amphipods (Corophium volutator or Leptocheirus plumulosis).

In the North Sea, base oils and chemicals used during drilling must undergo aquatic toxicity testing for hazard evaluation (OSPAR, 1995a, 1995b). All the tests are carried out on three aquatic species that represent the food chain. The most common species are the marine alga (Skeletonema costatum), the copepod (Acartia tonsa), the juvenile turbot Scophthalamus maximus for which aqueous phase tests are performed, and a sediment reworker (Corophium volutator, sediment dwelling amphipod) for which the sediment phase is used during the toxicity test.

In the United States, discharge approval is based on compliance with effluent toxicity limits at the point of discharge. Therefore, discharge permits require measurement of the aquatic toxicity of the suspended particulate phase of drilling effluents to the mysid shrimp, Mysidopsis bahia. Moreover, guidelines have been recently published by USEPA (2001) where $E P A$ requires two other toxicity tests:

- all synthetic base fluids to be discharged with cuttings have to be no more toxic than a $\mathrm{C}_{16}-\mathrm{C}_{18}$ internal olefin base fluid, according to a 10-days sediment toxicity test (ASTME E 1367-92) with Leptocheirus plumulosis (amphipods);

- drilling fluids used offshore must undergo a 4-days toxicity test with Leptocheirus plumulosis prior to cuttings discharge, and they must be no more toxic than a $\mathrm{C}_{16}-\mathrm{C}_{18}$ formulated drilling mud.

\subsubsection{Base Fluids Bioaccumulation}

Two types of data are generally used to estimate a chemical's bioaccumulative potential: the octanol/water partition 
coefficient and the bioconcentration factor. The octanol/ water partition coefficient (often expressed as log Pow) is a physicochemical measure of a component's tendency to partition into octanol relative to water. It is generally admitted that chemicals with log Pow between 3 and 6 bioaccumulate significantly, chemicals with log Pow greater than 6 do not readily bioaccumulate in relation to their lipophilicity (low bioavailability), and finally, those with log Pow lower than 3 tend to desorb back to the water phase and do not bioaccumulate.

The determination of a bioconcentration factor (BCF) is an in vivo measurement of bioaccumulative potential. In fact, an organism is exposed to a constant concentration of the tested chemical in water until equilibrium is reached between the concentration in water and the concentration in the tissues. The BCF is expressed as the tissue concentration divided by the water concentration at equilibrium. Then, compounds with $\log \mathrm{BCF}$ greater than 3 can bioaccumulate. Compounds with log BCF less than 3 are less likely to accumulate due to their high water solubility.

It is noteworthy that molecules with a molecular weight greater than 600 are considered as non bioaccumulable.

Generally, NABFs are not expected to bioaccumulate significantly. Their propensity to biodegrade further reduces the likelihood that exposures will be long enough that a significant bioaccumulative hazard will occur.

\subsection{Field Studies}

In addition to all these laboratory tests, several computer models exist that were designed to predict the behavior of drilling fluids and cuttings discharged into the sea. These models take into account input near the discharge point and characteristics of the effluent flow to predict the trajectory and the shape of discharge plumes, the concentrations of soluble and insoluble components in the water column and the accumulation of discharged solids in the seabed. But models are limited by the quality of the input data and generally do not account for resuspension and transport of particles after initial deposition. Consequently, the most realistic assessment of cuttings piles impacts can be provided by field studies. We will present hereafter the main conclusions of field studies that have been performed on different types of cuttings.

\subsubsection{WBF Cuttings}

There have been a number of WBF discharge seabed studies conducted in varying water depths and oceanographic environments. The scientific literature strongly supports the view that biological effects from WBF and WBF cuttings discharges depend essentially on the energy of the seafloor environment. Seafloor impacts may not be detectable in high energy environments (Lees and Houghton, 1980). When impacts are observed, in low energy environments, with deep water and slow bottom currents, they appear to be physical (alteration in sediment texture), highly localized and temporary (Smith et al., 1997). Davies et al. (1988) studied the long-term hydrocarbon persistence and biological recovery at 3 well sites (one drilled with WBF, one with diesel fluid and the other with LTMBF). Over 5 years after drilling, hydrocarbons were not detected and there was no observable impact on benthos at the WBF site.

\subsubsection{OBF Cuttings}

OBF cuttings are no longer discharged. But they have been discharged for many years in the North Sea and several other areas. The most comprehensive chemical and biological studies on the impact of such discharges were performed in the North Sea (Davies et al., 1988; Daan and Mulder, 1996; Olsgard and Gray, 1995). These studies showed that discharges of OBF cuttings had an adverse effect on the seabed biological fauna and that the major deleterious biological effects were confined to a $500 \mathrm{~m}$ zone around the well (Davies et al., 1988). A transition zone exists where less severe biological effects are detected. Biological parameters usually return to normal within 1000 m (Kingston, 1992). The extent of this transition zone are largely determined by the current regime and the scale of drilling operations (Davies et al., 1988). Cuttings piles persist today in some areas of the North Sea where high volumes of cuttings were discharged, due to the low biodegradability of fluids and the oceanographic conditions. $26 \mathrm{~m}$ high-cutting piles were documented in the deeper central and northern parts of the United Kingdom sector around 60 multi-well platforms (Neff et al., 2000). Typical piles are less than $10 \mathrm{~m}$ high and have footprints less than $50 \mathrm{~m}$ in diameter.

Davies et al. (1988) studied the long-term hydrocarbon persistence and biological recovery at 3 well sites (one drilled with diesel oil). Over 5 years after drilling, hydrocarbons were detected at $2500 \mathrm{~m}$ and a significant reduction in species diversity was observed between 50 and $500 \mathrm{~m}$ at the diesel site.

\subsubsection{LTMBF Cuttings}

Cutting piles from LTMBF cuttings have been much less studied than OBF cuttings (Davies et al., 1988; Oliver and Fisher, 1999). Many of the North Sea studies concern wells were both diesel and LTMBF NADF cuttings have been discharged, and no differentiation is made between impacts from the two. The physical behavior and biological impacts of LTMBF cuttings with varying oil concentration were also studied using laboratory tests and computer modeling, and field and laboratory simulations (E\&P Forum, 1996). Davies et al. (1988) studied the long-term hydrocarbon persistence and biological recovery at 3 well sites (one drilled with LTMBF). Over 5 years after drilling, hydrocarbons were detected at $750 \mathrm{~m}$ for the LTMBF and a significant reduction 
in species diversity was observed between 50 and $200 \mathrm{~m}$ at the LTMBF site. A study initiated by Ifremer and Total is underway on the continental margin offshore Angola, Congo and Gabon (OGP, 2003). Eight wells have been drilled in the area studied since 1998 and HDF200 (LTMBF) cuttings have been discharged. Previous studies provided data on the general structure of the benthic communities and on chemical characteristics of the sediment near well stations (Block 17$1350 \mathrm{~m}$ depth). Biological and chemical data obtained between stations at $200 \mathrm{~m}$ and $10 \mathrm{~km}$ away from well stations were compared and showed no significant differences for most of the parameters from the preliminary observations. No contamination by aromatic hydrocarbons was observed in the superficial sediment, but an unexpected richness in organic carbon in the sediment was identified down to $15 \mathrm{~cm}$. The macrofaunal density was found similar to that observed in other deep sea sediments. Finally, sessile fauna was absent due to the fluidity of the sediment.

\subsubsection{SBF Cuttings}

Field studies have been performed on the impacts from SBF cuttings discharges. At many sites where SBFs have been used there is a previous history of WBF and LTMBF cuttings discharge; it is therefore often difficult to differentiate the respective impacts of each type of cuttings. Furthermore, few field studies have documented the impact on biological communities: Terrens et al. (1998) (esters, Australia), Oliver and Fisher (1999) (linear paraffins, Australia), Daan et al. (1996) (esters, North Sea), Neff et al. (2000) (linear paraffins, North Sea), Candler et al. (1995) (poly-alpha-olefins, Gulf of Mexico), Fechelm et al. (1999) (linear-alpha-olefins+esters, Gulf of Mexico), etc. The main conclusions of these studies are the following:

- Discharge from LTMBF and SBF cuttings may have lower impacts than with OBF cuttings.

- Areas that recover most rapidly are those with highenergy seabed conditions.

- Several studies on SBF cuttings discharge showed evidence of anaerobic conditions (black sediment); it is consistent with base fluid biodegradation leading to anoxic conditions in the sediment.

- Esters are less persistent in the environment and exhibit less toxicity to sediment organisms compared to other NABFs, but a systematic analysis of North Sea data (Jensen et al., 1999) concluded that olefins had fewer biological effects than esters. The impacts may certainly arise from oxygen depletion.

- It is probable that within 3 to 5 years of cessation of SBF cuttings discharge, complete recovery will be possible (Neff et al., 2000). In all SBF cuttings discharge studies, benthic communities showed signs that recovery had begun within one year following cuttings discharge.

\section{MATERIALS AND METHODS}

\subsection{Drilling Fluids and Cuttings Samples}

The different samples studied were as follows:

- a glycol-based mud (water-based mud) and the corresponding cuttings;

- two different paraffinic oil-based muds (H oil and X oil) and the corresponding cuttings;

- diesel oil-based cuttings.

Cuttings were sampled on drilling platforms after separation in shale-shakers.

\subsection{Sediments Sampling at the Discharge Site}

Sampling was carried out during 3 days in March 2002, by means of a Van Veen grab that allowed to sample an area of about $0.1 \mathrm{~m}^{2}$ of sediment.

At each station, one grab was removed for physicochemical analyses and toxicity tests, and three for the analysis of benthic communities. For the specific case of benthic analysis, samples from the grabs were put into a barrel and mixed until an homogeneous suspension was obtained. Then, samples were sieved on a $1 \mathrm{~mm}$ stainless steel mesh sieve. After sea water flushing, the oversize was put into a plastic bag with formol and sea water (with some "Bengale pink").

\subsection{Physicochemical Analyses on Sediments}

The different physicochemical analyses performed on the sediment (Redox potential, granulometry, water content, organic matter, total nitrogen and phosphorus, total hydrocarbons and barium) are listed in Table 1. Oxidation-reduction potentials were measured directly on boat during sampling with a Ponselle potentiometer linked to a platinum electrode and an $\mathrm{AgCl}_{2}$ reference electrode.

\subsection{Lixiviation Tests}

For base fluids, a contact was performed at $20^{\circ} \mathrm{C}$ for $72 \mathrm{~h}$ from $20 \mathrm{ml}$ of base fluid to 1.9801 of distilled water under gentle agitation. For cuttings, about $6 \mathrm{~g}$ of dry material were shaken with $250 \mathrm{ml}$ of distilled water at $20^{\circ} \mathrm{C}$ for $48 \mathrm{~h}$ on a rotary shaker at $10 \mathrm{rpm}$. For sediments originated from discharged site, $6 \mathrm{~g}$ of dry material were used with $250 \mathrm{ml}$ of water and both 6 and $60 \mathrm{~g}$ for the two samples nearest the discharge point. The aqueous phase (leachate) was then centrifuged and filtered on a regenerated cellulose $(0.45 \mu \mathrm{m})$. Hydrocarbons (SPME/GC), total organic carbon (TOC), and acute toxicity (Microtox test) were determined on filtered leachate. 
TABLE 1

Physicochemical analyses performed on the sediments

\begin{tabular}{c|c|c}
\hline Tests & Methods & Detection limit \\
\hline Laser granulometry & Laser Coulter LS230 & $0.4 \mu \mathrm{m}$ \\
\hline Organic matter & Pr EN 12879 & $0.1 \%$ dry weight \\
\hline Water content & NF ISO 11465 & - \\
\hline Total nitrogen & NF ISO 11261 & $0.01 \%$ dry weight \\
\hline Total phosphorus & NF EN 1189 & $0.01 \%$ dry weight \\
\hline $\begin{array}{c}\text { Mineralization } \\
\text { for barium dosage }\end{array}$ & $\begin{array}{c}\text { Total attack } \\
\text { in acid medium }\end{array}$ & - \\
\hline Barium & ICP & $5 \mathrm{mg} / \mathrm{kg}$ dry weight \\
\hline Total hydrocarbons & XP T 90-114 mod. & $10 \mathrm{mg} / \mathrm{kg}$ dry weight \\
\hline
\end{tabular}

\subsection{Hydrocarbons Analysis in Drilling Muds, Cuttings, and Sediments}

Ten grams of samples (cuttings, or drilling muds or sediments) expressed in dry weight, were extracted twice with $100 \mathrm{ml}$ of a mixture of cyclohexane/acetone (85/15, v/v). Solvent extracts were analyzed by gas chromatography (GC). A column DB5 (phase thickness film $0.1 \mu \mathrm{m}$, length $60 \mathrm{~m}$, internal diameter $0.25 \mathrm{~mm}$ ) was used. The analytical conditions were: injector temperature profile: 50 to $280^{\circ} \mathrm{C}$ at $180^{\circ} \mathrm{C} \mathrm{min}^{-1}$; oven temperature profile: $50^{\circ} \mathrm{C}$ during $10 \mathrm{~min}$, then increase to $310^{\circ} \mathrm{C}$ at $2^{\circ} \mathrm{C} \mathrm{min}^{-1}$; detector temperature: hold at $310^{\circ} \mathrm{C}$. The respective quantifications were done with corresponding base oil as calibration standard (diesel oil for diesel oil-based cuttings, $\mathrm{H}$ oil and $\mathrm{X}$ oil for the two different paraffinic oilbased muds and associated cuttings).

\subsection{Hydrocarbon Analysis of Leachates}

Hydrocarbons in the leachates originating from base oils, cuttings and sediments were analyzed combining SPME (solid phase microextraction) technique with GC. An SPME headspace procedure was used with a fiber coated with a $100 \mu \mathrm{m}$-thickness film of polydimethylsiloxane phase according to the methodology described by Pawliszyn (1997). External calibration was done with a mixture of volatile organic compounds (VOC 524 from Supelco).

\subsection{Toxicity Tests}

Three tests recommended by OSPAR were performed, respectively on a sediment reworker, on copepods and on larvae of fish. Two other tests were additionally used: on larvae of mollusks and on a marine bacteria (Microtox test).

\subsubsection{Toxicity Tests on Sediment Reworker}

The tests were performed on Corophium arenarium in presence of sediment at $15^{\circ} \mathrm{C}$ (method according to the project ISO/CD 16712). Drilling muds, cuttings or polluted sediments were mixed with an unpolluted sediment. The different dilutions of the sediment were placed into containers. Filtrated and aerated natural sea water was added (at least 5 times more than sediment volume). 10 Corophia were placed in each container (20 individuals/concentration). At the end of the test (10 days), sediment was sieved and the number of individuals still alive was measured in order to calculate concentrations inducing death of 50 and $20 \%$ of animals population $\left(\mathrm{LC}_{50}\right.$ and $\left.\mathrm{LC}_{20}\right)$.

\subsubsection{Toxicity Tests on Copepods}

The tests were performed with Acartia tonsa (norm ISO 14669) on drilling mud and cuttings sea water contacts. $240 \mathrm{~g}$ of drilling mud or cuttings materials were suspended with agitation in 11 synthetic sea water, for $8 \mathrm{~h}$. The clarification of the water phase was done by centrifugation for $10 \mathrm{~min}$ at $3000 \mathrm{~g}$. Copepods were distributed in different diluted solutions of water phase contact in the sea water (20 individuals/concentration). Animals still alive were counted at the end of the test $\left(48 \mathrm{~h}\right.$ at $\left.20^{\circ} \mathrm{C}\right)$ in order to calculate concentrations inducing death of $50 \%$ of animals $\left(\mathrm{LC}_{50}\right)$.

\subsubsection{Toxicity Test on Fish Larvae}

The tests on fish were carried out on juveniles (larvae) of sea bass (Dicentrarchus labrax) (OECD Guideline 203 modified according to OSPARCOM 1995 for the methodology NFT90-307). Larvae of about $0.5 \mathrm{~g}$ weight originated from Gravelines (France). Different drilling mud or cuttings dilutions in aerated sea water (with a maximum concentration of $10 \mathrm{~g} / \mathrm{l})$ were placed in an aquarium. Four fishes were used per aquarium and 8 fishes per concentration. The lighting cycle was $16 \mathrm{~h}$ of light $/ 24 \mathrm{~h}$. The tests were conducted with simple contact, or with agitation between drilling muds (or cuttings), and seawater $(4 \mathrm{~h})$, for $96 \mathrm{~h}$ at $19^{\circ} \mathrm{C}$. The concentration inducing $50 \%$ of mortality was determined.

\subsubsection{Toxicity Test on Mollusks}

The larval development of mollusks (His et al., 1999) (oysters or mussels) was examined against dilutions of sea water phase contact with drilling muds, cuttings or polluted sediments. $60 \mathrm{~g}$ of samples to be tested was mixed with $240 \mathrm{ml}$ of filtered natural sea water and agitated during $8 \mathrm{~h}$. After $8 \mathrm{~h}$ of decantation, the supernatant phase (leachate) was recovered and diluted. Sterile culture microplates IWAKI with $3 \mathrm{ml}$-wells were filled with the different dilutions (5 wells/concentration). 300 mollusks larvae ${ }^{1}$ were inserted

1 Obtention of mollusks larvae: mature sires of oysters (Guernesey sea farms, United Kingdom) or mussels ("Étang de Thau", France) were put into the reference sea water (nonfiltered) at $18^{\circ} \mathrm{C}$ during $30 \mathrm{~min}$. A thermal chock was then imposed at $28^{\circ} \mathrm{C}$, during $30 \mathrm{~min}$, which led to gametes emission. Fecundation was achieved by adding $3 \mathrm{ml}$ of sperm suspension into a female gamete suspension $(250 \mathrm{ml}$-test tube completed with filtered sea water). 
in each well and the plates were incubated at $23^{\circ} \mathrm{C}$ during $24 \mathrm{~h}$. The level of anomalies were then determined after the counting of 100 larvae per concentration under the microscope. Results were expressed in \% of anomalies versus leachate concentration or in effective concentration (EC) that causes 20 or $50 \%$ of anomalies.

\subsubsection{Toxicity Test on Bacteria (Doherty, 2001; Stronkhorst et al., 2003)}

Acute toxicity was determined with the Microtox test according to standard methods (AFNOR T90-320). Toxicity tests were carried out on base fluids, cuttings and polluted sediments. $500 \mu 1$ of bacterial suspension of Vibrio fischeri (Microtox Acute Reagent, Microbics Corporation) were allowed to incubate at $15^{\circ} \mathrm{C}$ for $5 \mathrm{~min}$; then an initial light reading was taken. Aliquots of $500 \mu \mathrm{l}$ from each leachate dilutions (lixiviation tests) were added to the bacterial suspension. At $30 \mathrm{~min}$ after addition a final light reading was taken. Toxicity was correlated to bioluminescence decrease. The results were expressed as the maximal inhibition $\left(I_{\max }\right)$ of bioluminescence for the undiluted leachate (referred to as maximal inhibition in \%) and as $\mathrm{EC}_{50}$, the effective dilution of the tested solution which induced a bioluminescence inhibition of $50 \%$.

\subsection{Aerobic Biodegradation}

Aerobic biodegradation tests were performed on base oils, muds, cuttings and sediments in stirred flask reactors in a Sapromat respirometer (type D or E, Voith, Ravensburg, Germany) as described by Bouchez et al., (1997). For base oils, muds and cuttings, activated sludge (aerobic process) from a wastewater treatment plant (Achères, France) which mainly receives domestic wastewater was used as inoculum. Hydrocarbons were quantified by GC before and after biodegradation test. $\mathrm{O}_{2}$ consumption was monitored.

Aerobic biodegradation tests on the cuttings originated from discharge site samples (sediments) were also performed using a Sapromat respirometer. The indigenous flora was used as inoculum. The culture medium was a reconstituted sea water with the following composition: $\mathrm{NaCl}: 23.9 \mathrm{~g} / 1 ; \mathrm{MgCl}_{2}$, $6 \mathrm{H}_{2} \mathrm{O}: 10.8 \mathrm{~g} / \mathrm{l} ; \mathrm{CaCl}_{2}: 0.1 \mathrm{~g} / \mathrm{K} ; \mathrm{KCl}: 0.74 \mathrm{~g} / \mathrm{l} ; \mathrm{Na}_{2} \mathrm{SO}_{4}: 4.0 \mathrm{~g} / \mathrm{l}$; $\mathrm{NaHCO}_{3}: 0.196 \mathrm{~g} / \mathrm{l} ; \mathrm{K}_{2} \mathrm{HPO}_{4}: 0.07 \mathrm{~g} / \mathrm{l} ; \mathrm{NH}_{4} \mathrm{Cl}: 0.9 \mathrm{~g} / \mathrm{l} ; \mathrm{NaBr}$, $2 \mathrm{H}_{2} 0: 0.117 \mathrm{~g} / \mathrm{l}$; and $10 \mathrm{ml}$ of a trace elements solution at $\mathrm{pH} 2$ with $\mathrm{HCl}\left(\mathrm{H}_{3} \mathrm{BO}_{3}: 23 \mathrm{mg} / \mathrm{l} ; \mathrm{NaF}: 2 \mathrm{mg} / \mathrm{l} ; \mathrm{SiO}_{2} \mathrm{Na}_{2} \mathrm{O}, 5 \mathrm{H}_{2} \mathrm{O}\right.$ : $\left.22 \mathrm{mg} / \mathrm{l} ; \mathrm{FeSO}_{4}, 7 \mathrm{H}_{2} \mathrm{O}: 2 \mathrm{mg} / \mathrm{l}\right)$. The medium $\mathrm{pH}$ was adjusted to 8.2 with $5 \mathrm{M} \mathrm{KOH}$. Hydrocarbons were dosed by GC before and after biodegradation.

\subsection{Anaerobic Biodegradation}

Anaerobic biodegradation tests were carried out on the base oils and 4 sediments (stations 2, 4, 6, 13, campaign 2002).
The test procedure is adapted from the ECETOC procedure Draft Technical Report $N^{\circ} 28$ (Blanchet et al., 1998). For the base oils, anaerobic digested sludge from a wastewater treatment plant (Achères, France) which mainly receives domestic wastewater was used as inoculum. $9 \mathrm{ml}$ of anaerobic centrifuged sludge was introduced in an oxygen-free mineral medium $(89 \mathrm{ml})$ in penicillin vials. For sediments, tests were conducted with the indigenous flora.

Prior to sealing the flasks, $20 \mu \mathrm{l}$ of the base oil or of $20 \mu \mathrm{l}$ of a mixture of base oil ( $\mathrm{H}$ or $\mathrm{X}$ oils) and esters based oil (75/ $25 \% \mathrm{v} / \mathrm{v}$ ) were added. Blanks (assay without substrate) and controls (assays on fructose, $20 \mathrm{mg}$, and esters based oil, $20 \mu \mathrm{l})$ were prepared similarly. The vials were statically incubated at $30^{\circ} \mathrm{C}$. The $\mathrm{pH}$ of test was $6.5-7.2$. The vials were gently shaken once a week to enhance the contact between floc-forming bacteria and insoluble substrate. Penicillin flasks presented headspace sufficient for evolved gases. Biogas production resulting from the degradation of chemical substances was quantified by measuring the pressure increase in the sealed flasks once a week, using a differential pressure transducer (scanivalve pressure transducer Type PDCR 22, operating pressure range 3.5 bar). The atmospheric pressure was recorded, for correction to absolute pressure in the headspace.

\subsection{Abundance and Diversity of the Benthic Fauna}

All the species were identified under binocular microscope and numbered. Then, for each of the seven stations, the density of each species, the specific richness (number of species) as well as the total density (total number of individuals $/ \mathrm{m}^{2}$ ) were determined. The trophic group that includes each species was determined in order to calculate the trophic index to appreciate the effect of accumulation of organic matter at sea bottom. The different trophic groups were the following (Word, 1990):

- group 1: suspension-feeders;

- group 2: flesh-feeders;

- group 3: deposit-feeders;

- group 4: anaerobic sediments-feeders.

The formula for the trophic index $T I$ was the following:

$T I=100-\left[33.33\left(\left(0 n_{1}+1 n_{2}+2 n_{3}+3 n_{4}\right) /\left(n_{1}+\mathrm{n}_{2}+\mathrm{n}_{3}+\mathrm{n}_{4}\right)\right)\right]$

Where $n_{1}, n_{2}, n_{3}$ and $n_{4}$ correspond to the respective abundance of trophic groups 1 to 4 . Hence, three intervals can be identified to determine the level of settlement:

- $T I>$ 60: normal settlement, characterized by a domination of suspension-feeder species (absence of accumulation of organic matter in the sediment);

- $30<T I<60$ : settlement submitted to organic matter inputs (presence of deposit-feeder species); 
- $T I$ < 30: settlement submitted to perturbation factors (settlement dominated by deposit-feeders and anaerobic sediments-feeders species, showing a high accumulation of organic matter in the sediment).

The Shannon-Wiener diversity index $H$ (expressed in bits) and the Pielou equitability index $J$ (expressed in \%) were calculated as following:

$$
\begin{gathered}
H=-\sum_{i=1}^{s}\left[n_{i} / N \log _{2}\left(n_{i} / N\right)\right] \\
J=H / H_{\max }
\end{gathered}
$$

where $s$ is the total number of species, $N$ is the total number of individuals, $n_{i}$ is the number of individuals of each species $i$ and $H_{\max }=\log _{2} s$.

The biomass (dry weight) from each species was expressed from the average value of the weight of several individuals after $24 \mathrm{~h}$ drying at $70^{\circ} \mathrm{C}$. In the case of shell organisms, the dry weight without ash was determined after calcination for 4 $\mathrm{h}$ at $400^{\circ} \mathrm{C}$.

\section{RESULTS}

\subsection{Biodegradability and Toxicity Properties of Drilling Products (Muds and Cuttings)}

The first phase of this project on the effects of discharged cuttings was dedicated to the study of 4 types of drilling fluids and cuttings from an ecotoxicological point of view: chemical analysis of hydrocarbons, aquatic and sediment toxicity, aerobic and anaerobic biodegradation, lixiviation. The main objective was to select and validate the most suitable methods for the continuation of the project.

\subsubsection{Lixiviation of Drilling Products}

Results from the lixiviation tests, expressed in terms of total organic carbon (TOC) and soluble hydrocarbons, are indicated in Table 2. The amount of soluble hydrocarbons, measured by SPME, did not exceed $646 \mu \mathrm{g} / \mathrm{l}$, the maximum value whatever the nature of the cuttings. As expected, the diesel oil cuttings released much more hydrocarbons than others. These results are consistent with those obtained from the contact tests between base oils (diesel oil, $\mathrm{X}$ base oil and $\mathrm{H}$ base oil) and water. As a matter of fact, concentration of soluble hydrocarbons in water after contact reached $2600 \mu \mathrm{g} / \mathrm{l}$ for diesel oil and the values of $20-70 \mu \mathrm{g} / \mathrm{l}$ for the dearomatized oils $\mathrm{X}$ and $\mathrm{H}$ (saturation conditions with $10 \mathrm{ml}$ of base fluid in contact with 11 water).

On the other hand lixiviation tests with the different cuttings released a great amount of organic matter (expressed as total organic carbon), especially in the case of water based mud cuttings. It is noteworthy that the major part of the organic matter release from the different cuttings does not come from soluble hydrocarbons (perhaps high solubility of glycol compounds, or pseudo-emulsification of compounds).

\subsubsection{Aquatic and Sediment Toxicity}

Microtox toxicity was applied to the leachates of cuttings (see upon lixiviation tests). Cuttings were not found toxic (Table 2). However, surprisingly, the maximum of inhibition of the bacteria activity was found with $\mathrm{X}$ and $\mathrm{H}$-cuttings (respectively 41 and 24\%), while diesel oil cuttings showed no detectable inhibition. This toxicity is likely due to other components than hydrocarbons (see upon analytical results on leachates).

TABLE 2

\begin{tabular}{|c|c|c|c|c|c|}
\hline \multirow[t]{2}{*}{ Products } & \multirow[t]{2}{*}{$\begin{array}{c}\text { Total carbon } \\
\text { in leachates }(\mathrm{mg} / \mathrm{l})\end{array}$} & \multirow[t]{2}{*}{$\begin{array}{c}\text { Total organic carbon } \\
\text { in leachates }(\mathrm{mg} / \mathrm{l})\end{array}$} & \multicolumn{2}{|c|}{$\begin{array}{l}\text { Hydrocarbons in leachates } \\
\qquad(\mu \mathrm{g} / \mathrm{l})\end{array}$} & \multirow{2}{*}{$\begin{array}{c}\text { Microtox toxicity } \\
I_{\max }(\%)\end{array}$} \\
\hline & & & BTEX & Soluble HC* & \\
\hline Diesel oil & & & 1010 & 2602 & 42.3 \\
\hline $\mathrm{X}$ base oil & & & 6 & 48 & $<$ threshold \\
\hline $\mathrm{H}$ base oil & & & $\begin{array}{c}2 \\
0.4\end{array}$ & $\begin{array}{l}20 \\
68 \\
\end{array}$ & $<$ threshold \\
\hline $\mathrm{X}$ Cuttings & 40.6 & 39.1 & 4 & 49 & 41 \\
\hline Glycol Cuttings & 362.3 & 354.0 & 3 & 36 & $<$ threshold \\
\hline Diesel oil Cuttings & 15.5 & 14.8 & 62 & 646 & $<$ threshold \\
\hline H Cuttings & 23.9 & 19.3 & 6 & 46 & 24 \\
\hline
\end{tabular}

Lixiviation and Microtox test on leachate

With base oils, a contact was performed between oil and water.

$I_{\max }$ is the maximum inhibition of bacteria luminescence in presence of the maximum concentration in the test tube (= leachate diluted at $\left.50 \%\right)$. Minimal threshold of inhibition: $20 \%$.

* Soluble HC: BTEX are comprised in the total of the soluble fraction. $\mathrm{X}$ and $\mathrm{H}$ cuttings are cuttings corresponding to $\mathrm{X}$ and $\mathrm{H}$ base oils respectively. 
TABLE 3

Toxicity test on Acartia tonsa (copepod)

\begin{tabular}{l|c|c|c|c}
\hline Tested product & \multicolumn{4}{|c}{$\mathrm{LC}_{50}(\%$ of dilution of the initial leachate $)$} \\
\hline Base fluid & WBM (glycol) & H oil & X oil & Diesel oil \\
\hline Mud & 1.3 & 1.3 & 6.5 & 0.62 \\
\hline Cuttings & 1.5 & 2.3 & 11.3 & 10.1 \\
\hline
\end{tabular}

Method ISO14669, $48 \mathrm{~h}$ at $20^{\circ} \mathrm{C}$, test on leachate $(8 \mathrm{~h}, 240 \mathrm{~g} / \mathrm{l})$ clarified by centrifugation $\left(10 \mathrm{~min}\right.$ at $3000 \mathrm{~g}$ ). $\mathrm{LC}_{50}$ is expressed as the percentage of dilution of the initial leachate.

TABLE 4

Toxicity test on Corophium arenarium (sediment reworker)

\begin{tabular}{l|c|c|c|c}
\hline Tested product & \multicolumn{4}{|c}{ Mortality at $10 \%(w / w)$ in a "blank" sediment } \\
\hline Base fluid & WBM (glycol) & H oil & X oil & Diesel oil \\
\hline Mud & $100 \%$ & $100 \%$ & $100 \%$ & $100 \%$ \\
\hline Cuttings & $70 \%$ & $100 \%$ & $85 \%$ & $100 \%$ \\
\hline
\end{tabular}

Project ISO/CD $16712(27 / 06 / 2001), 10$ days at $15^{\circ} \mathrm{C}$, dilutions in a "blank sediment".

TABLE 5

Toxicity test on Dicentrarchus labrax (fish)-simple contact

\begin{tabular}{l|c|c|c|c}
\hline \multirow{2}{*}{ Tested product } & \multicolumn{4}{|c}{ Mortality at $10 \mathrm{~g} / 1$} \\
\hline Base fluid & WBM (glycol) & H oil & X oil & Diesel oil \\
\hline Mud & $0 \%$ & $0 \%$ & $0 \%$ & $100 \% *$ \\
\hline Cuttings & $0 \%$ & $0 \%$ & $0 \%$ & $0 \%$ \\
\hline
\end{tabular}

Method OEDC Guideline 203 modified by OSPARCOM 1995 for the methodology NFT90-307 (June 1985), $96 \mathrm{~h}$ at $19^{\circ} \mathrm{C}$, simple contact.

$* \mathrm{LC}_{50}=1.4 \mathrm{~g} / 1$.

TABLE 6

Toxicity test on Dicentrarchus labrax (fish)-agitation

\begin{tabular}{l|c|c|c|c}
\hline \multirow{2}{*}{ Tested product } & \multicolumn{4}{|c}{ Mortality at $10 \mathrm{~g} / 1$} \\
\hline Base fluid & WBM (glycol) & H oil & X oil & Diesel oil \\
\hline Mud & $0 \%$ & $50 \% *$ & $0 \%$ & Nontested \\
\hline Cuttings & $0 \%$ & $100 \% * *$ & $0 \%$ & $10 \%$ \\
\hline
\end{tabular}

Method OEDC Guideline 203 modified by OSPARCOM 1995 for the methodology NFT90-307 (June 1985), $96 \mathrm{~h}$ at $19^{\circ} \mathrm{C}, 4 \mathrm{~h}$ of agitation.

$* \mathrm{LC}_{50}=10 \mathrm{~g} / \mathrm{l}$

$* * \mathrm{LC}_{50}=5.5 \mathrm{~g} / \mathrm{l}$
The tests carried out on copepods (Acartia tonsa, Table 3) showed that cuttings were less toxic than the corresponding drilling muds, especially in the case of diesel oil. These differences can be attributed to the weaker concentrations of the drilling base oils in the cuttings. A strong difference appeared between the two paraffinic oils ( $\mathrm{X}$ and $\mathrm{H})$ which can be explained by the fact that mud additives (surfactants, polymers, etc.) have obviously a great influence on the whole toxicity of muds and cuttings.

With the toxicity tests on sediment reworker with Corophium, $100 \%$ of mortality was observed with $10 \%$ of drilling mud incorporated into the blank sediment, whatever the base oil (Table 4). The mortality slightly decreased in presence of cuttings in the case of paraffinic oil $\mathrm{X}$ and water base mud with glycol. This effect is certainly due to the reduced amount of active matter in cuttings compared to muds.

Tests on fish larvae were performed with two procedures: simple contact between drilling muds or cuttings and sea water or agitation. The mortality observed for $10 \mathrm{~g} / 1$ (maximum concentration tested) of drilling muds or cuttings is given in Tables 5 and 6 . With a simple contact, no effect was observed except in the case of diesel oil muds where $100 \%$ mortality was found. The same test with agitation showed also a strong mortality in the case of muds and cuttings of paraffinic oil $\mathrm{H}$.

Results from the tests on oysters embryos (toxicity test on mollusks) are gathered in Table 7. This test appears as sensitive as the copepod test. In opposite to the latter one, it highlighted the highest toxicity for WB muds and WB cuttings. $100 \%$ of mortality were obtained for the highest dilution tested ( $3 \%$ leachate in sea water).

\subsubsection{Aerobic Biodegradation}

Aerobic biodegradation tests were carried out according to the respirometric procedure (measurement of the oxygen consumption). The inoculum was sampled from a sewage sludge (Achères sewage plant, France). For each tested sample, one control "inoculum" (for $\mathrm{O}_{2}$ consumption by inoculum), one control "abiotic" (for endogenous respiration of tested sample) and three assays for reproducibility (sample and inoculum) were performed. Hydrocarbons were dosed by GC before and after biodegradation in order to determine their percentage of degradation. Results are gathered in Tables 8, 9 and 10 .

Diesel oil cuttings showed a very high biodegradability in 45 days (see Table 10). For X and $\mathrm{H}$ respectively, biodegradability of base oils, muds and cuttings were compared. In the case of $\mathrm{H}$ base oil, both base oil, mud and cuttings were similarly biodegraded. For X (Fig. 1), differences in $\mathrm{O}_{2}$ consumption rates appeared depending on the type of sample (base oil, muds or cuttings). The quite good ratio $\left(\mathrm{O}_{2}\right.$ consumed)/(HC degraded) in all the samples, seems to reveal a problem of accessibility of hydrocarbons in the case of mud and cuttings. Only the base oil was entirely biodegraded. 
TABLE 7

Toxicity test towards the larval development of mollusks (oysters)

\begin{tabular}{c|c|c}
\hline Sample & $\begin{array}{c}\mathrm{EC}_{20} \\
(\% \text { leachate })\end{array}$ & $\begin{array}{c}\mathrm{EC}_{50} \\
(\% \text { leachate })\end{array}$ \\
\hline Base oil H & $10.4(0.3)$ & $16.9(0.5)$ \\
Mud 1 & $8.8(0.4)$ & $10.6(0.3)$ \\
Mud 2 & $14.6(1.3)$ & $17.5(1.2)$ \\
Cuttings 1 & $14.4(0.3)$ & $17.0(0.3)$ \\
Cuttings 2 & & \\
\hline WBM glycol & $100 \%$ mortality $(*)$ & $100 \%$ mortality $(*)$ \\
Mud S1 & $100 \%$ mortality $(*)$ & $100 \%$ mortality $(*)$ \\
Mud S2 & $100 \%$ mortality $(*)$ & $100 \%$ mortality $(*)$ \\
Cuttings S1 & $100 \%$ mortality $(*)$ & $100 \%$ mortality $(*)$ \\
Cuttings S2 & $13.2(0.9)$ & $23.4(2.1)$ \\
\hline Diesel oil cuttings & \multicolumn{2}{|c}{}
\end{tabular}

Test on leachate $(8 \mathrm{~h}, 60 \mathrm{~g}$ in $240 \mathrm{ml}$ sea water) clarified by decanting (8 h) (His et al., 1999). Results are expressed as the effective concentration causing 20 or $50 \%$ of larval anomalies. Values in brackets ( ): confidence interval $95 \%$.

$* 100 \%$ mortality for the maximal dilution of leachate tested (3\% leachate in seawater).

TABLE 8

Aerobic biodegradation tests for $\mathrm{X}$ oil, mud and cuttings (55 days)

\begin{tabular}{l|c|c|c|c|c}
\hline \multicolumn{1}{c|}{ Characteristics } & X oil & \multicolumn{2}{|c|}{ X-based mud } & \multicolumn{2}{c}{$\begin{array}{c}\text { X-based } \\
\text { cuttings }\end{array}$} \\
\hline $\begin{array}{l}\text { Initial } \\
\text { hydrocarbons (mg) }\end{array}$ & 154 & 258 & 338 & 229 & 258 \\
\hline $\begin{array}{l}\text { Degraded } \\
\text { hydrocarbons (mg) }\end{array}$ & 154 & 110 & 101 & 53 & 27 \\
\hline Degraded HC (\%) & 100 & 43 & 30 & 23 & 11 \\
\hline $\mathrm{O}_{2}$ consumption (mg) & 490 & 299 & 215 & 97 & 92 \\
\hline $\mathrm{O}_{2}$ cons./ degraded HC & 3.2 & 2.7 & 2.1 & 1.8 & 3.4 \\
\hline
\end{tabular}

\section{TABLE 9}

Aerobic biodegradation tests for $\mathrm{H}$ oil, mud and cuttings (75 days)

\begin{tabular}{l|c|c|c|c|c|c}
\hline \multicolumn{1}{c|}{ Characteristics } & \multicolumn{2}{|c|}{ H oil } & \multicolumn{2}{c|}{ H-based mud } & $\begin{array}{c}\text { H-based } \\
\text { cuttings }\end{array}$ \\
\hline $\begin{array}{l}\text { Initial } \\
\text { hydrocarbons (mg) }\end{array}$ & 162 & 162 & 431 & 451 & 451 & 222 \\
\hline $\begin{array}{l}\text { Degraded } \\
\text { hydrocarbons (mg) }\end{array}$ & 160 & 157 & 382 & 396 & 382 & 217 \\
\hline Degraded HC (\%) & 99 & 97 & 89 & 88 & 85 & 98 \\
\hline $\mathrm{O}_{2}$ consumption (mg) & 452 & 469 & 1207 & 1262 & 1343 & 572 \\
\hline $\mathrm{O}_{2}$ cons./degraded HC & 2.8 & 3.0 & 3.2 & 3.2 & 3.5 & 2.6 \\
\hline
\end{tabular}

TABLE 10

Biodegradability of diesel oil-based cuttings (45 days))

\begin{tabular}{l|c}
\hline \multicolumn{1}{c|}{ Characteristics } & Diesel oil cuttings \\
\hline Initial hydrocarbons $(\mathrm{mg})$ & 540 \\
Degraded hydrocarbons $(\mathrm{mg})$ & 506 \\
Degraded HC $(\%)$ & 94 \\
$\mathrm{O}_{2}$ consumption $(\mathrm{mg})$ & 1001 \\
$\mathrm{O}_{2}$ cons./ degraded HC & 2.0 \\
\hline
\end{tabular}

In the case of WBM cuttings (with glycol) the $\mathrm{O}_{2}$ consumption curves are presented in Figure 2. The $\mathrm{O}_{2}$ consumption was quite proportional to the quantities of wet material (between 4 and $8 \mathrm{~g}$ ) and attained definitively a plateau between 20 and 30 days of degradation. These cuttings coming from drilling with a water based mud, no dosage of hydrocarbons was performed. In that case, biodegradation likely concerns the organic matter other than hydrocarbons, as shown by the results of TOC from the lixiviation tests (Table 2).

\subsubsection{Anaerobic Biodegradation}

Anaerobic biodegradation tests were carried out according to the ECETOC procedure. The inoculum originated from the anaerobic digester of a sewage plant. Biogas production $\left(\mathrm{CH}_{4}\right.$ and $\mathrm{CO}_{2}$ ) resulting from the biodegradation of chemical substrates in anaerobic conditions was quantified by measuring the net pressure evolution. Figure 3 presents the evolution of the pressure increase and does not include the inorganic carbon which is dissolved in the liquid medium. $\mathrm{X}$ base oil, $\mathrm{H}$ base oil, diesel oil, esters, and binary mixtures [esters $+\mathrm{H}$ base oil or esters $+X$ base oil $(25 / 75 \%, v / v)]$ were tested.

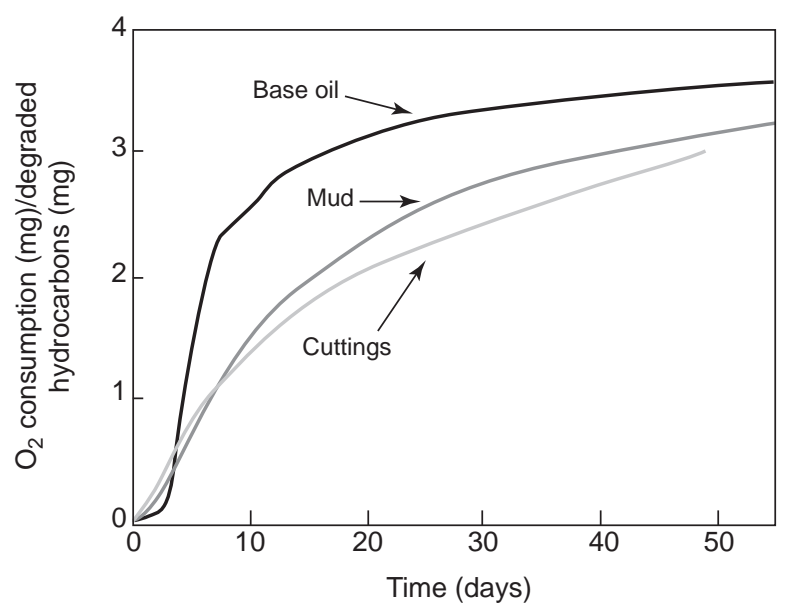

Figure 1

Kinetics of aerobic biodegradation of base oil $\mathrm{X}$ and corresponding mud and cuttings. $\mathrm{O}_{2}$ consumption was determined by using a Sapromat respirometer (endogenous respiration around $61 \mathrm{mg} \mathrm{O}_{2}$ after 55 days). 


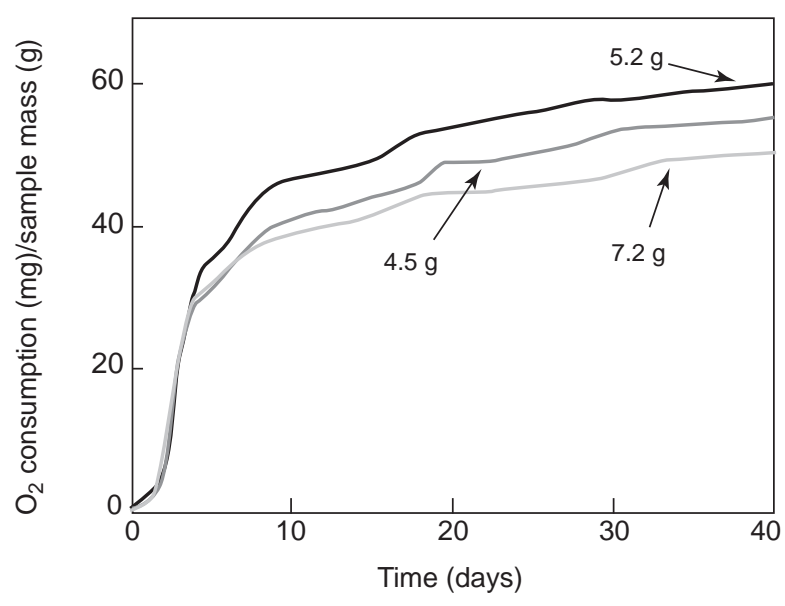

Figure 2

Kinetics of aerobic biodegradation of water base mud cuttings with glycol (Sapromat procedure).

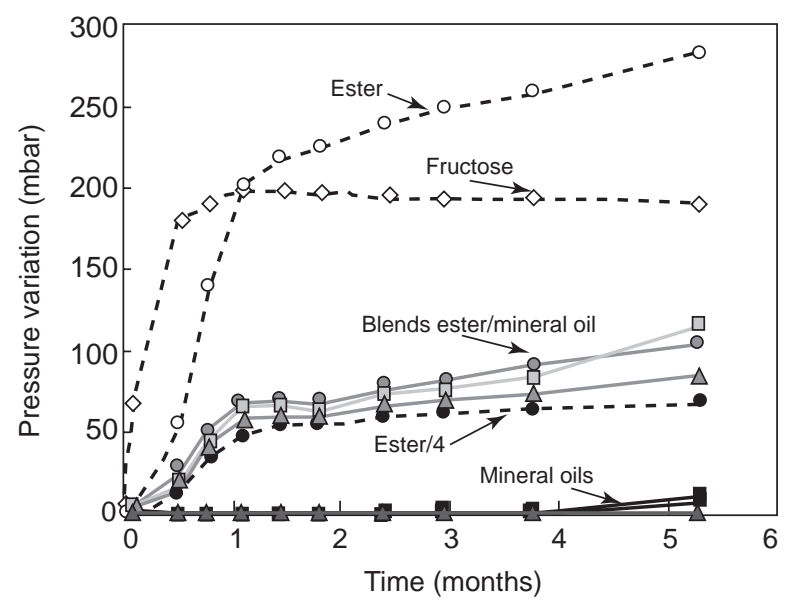

Figure 3

Kinetics of anaerobic biodegradation of mineral base oils (circle: $\mathrm{H}$, triangle: $\mathrm{X}$ and square: diesel oil), vegetable base oil (empty circle: ester), and mixtures of ester/mineral oil 25/75\% (circle: ester/H, triangle: ester/X and square: ester/diesel oil), ECETOC procedure with fructose as reference.

After 160 days, biodegradation was only observed in the case of reference substances (fructose and ester), and binary mixtures including esters. Previous study has demonstrated that the ultimate biodegradation percentage of ester, based on the net production of $\mathrm{CO}_{2}$ and $\mathrm{CH}_{4}$, reached $45 \%$ in such conditions (Blanchet et al., 1998). Net pressures (before acidification) obtained for fructose and ester in our study were quite identical to those mentioned in the above study. In the case of mixtures of ester and paraffinic oil, the pressure obtained in the headspace was strictly due to the ester contribution in the mixture. No biodegradation occurred with the paraffinic oils (Fig. 3).

\subsection{Field Test: Recolonization of Sediments}

In this step, the study was intended to appreciate under real conditions the impact of cuttings, the capacity of regeneration of the ecosystem and the processes of recolonization. The most suitable measurements were taken within the framework of an in situ experiment at a discharge site in Congo (Africa). It is noteworthy that previous sampling and analyses were performed in 1995 (after the first step of drilling) and 2000 (one year and a half after the stop of cuttings discharge).

Campaign of sampling was operated in 2002, after 8 years of deposits. The sampling plan comprises 7 stations located on the same isobath $(180 \mathrm{~m})$ between 70 and $2000 \mathrm{~m}$ from the cuttings discharge point (Fig. 4, Table 11). It is noteworthy that station 2 can be considered as a "blank" station, as it is located out of the zone of impact of cuttings discharge. The sampling plan allowed the graphic representation of the evolution of the different variables as a function of the distance from the discharge point.

For each of the seven stations, physicochemical analyses of the sediments were associated to ecotoxicological tests (toxicity, biodegradation, lixiviation) and a complete analysis of benthos.

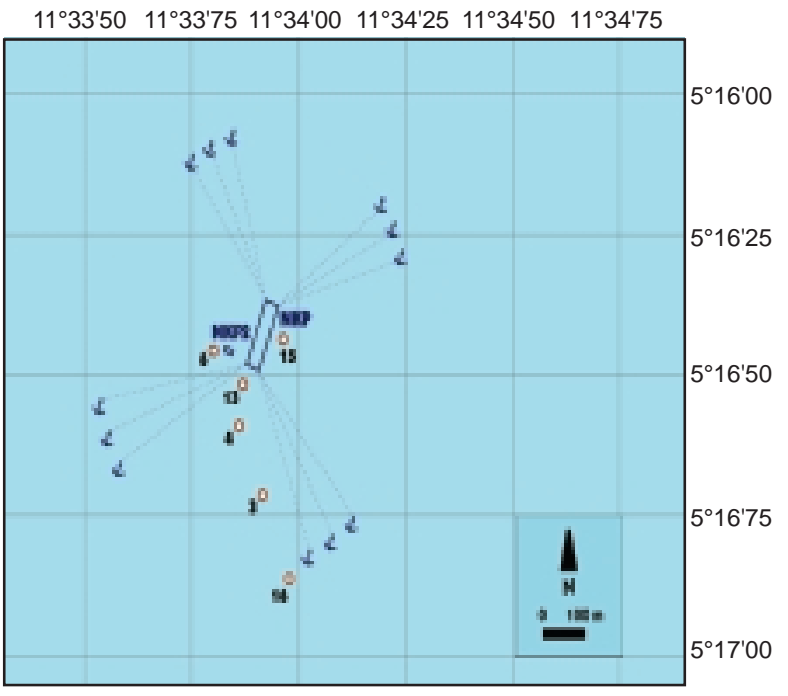

Figure 4

Sampling plan of the stations. 
TABLE 11

Sampling plan

\begin{tabular}{c|c}
\hline Station & Distance from the discharge point \\
\hline 2 & $2000 \mathrm{~m}$ South \\
16 & $730 \mathrm{~m}$ South \\
3 & $470 \mathrm{~m}$ South \\
4 & $230 \mathrm{~m}$ South \\
13 & $100 \mathrm{~m}$ South \\
15 & $180 \mathrm{~m}$ East \\
6 & $70 \mathrm{~m}$ West \\
\hline
\end{tabular}

\subsubsection{Physicochemical Characteristics of Sediments}

\section{Granulometry}

The natural sediment (station 2) showed a bimodal distribution: a fine fraction with a maximum distribution between 6 and $10 \mu \mathrm{m}$ and a sand fraction between 200 and $400 \mu \mathrm{m}$. Close to the point of discharge, the presence of cuttings was revealed by an additional distribution between 20 and $60 \mu \mathrm{m}$. The evolution of this class of particles characteristic of cuttings $(20-60 \mu \mathrm{m})$ is shown on Figure 5. A maximum was reached at station 13, close to the point of discharge $(100 \mathrm{~m}$ south). Compared to the analyses performed in 2000, no evolution in the nature of the sediment was observed.

\section{Nutrients}

The natural sediment was rich in nutrients: $11.3 \%$ of organic matter, $0.19 \%$ of total nitrogen and $1574 \mathrm{mg} / \mathrm{kg}$ of phosphorus. Whatever the distance from the discharge point, levels of organic matter and nitrogen were quite similar to the blank station. Phosphorus levels were found quite high except in the zone close to the discharge point $(<250 \mathrm{~m})$ : between 1000 and $1350 \mathrm{mg} / \mathrm{kg}$. No nutrients levels evolution was found between 2000 and 2002 .

\section{Oxidation Reduction Potential}

The Redox potential at stations near the discharge point was below $-250 \mathrm{mV}$, indicating strong reduction of the polluted sediment, and in consequence anaerobic metabolism. Then, the Redox potential progressively increased until $730 \mathrm{~m}$ from the discharge point (Fig. 6). The Redox potential at station 2 (blank station) was $+41 \mathrm{mV}$, proving that the natural sediment was sufficiently oxygenated to ensure conditions for aerobic degradation of natural organic matter.

This evolution of the Redox potential is probably correlated with the hydrocarbon concentrations in the sediment, as will be shown thereafter.

\section{Hydrocarbon Content}

Concentrations of hydrocarbons in the sediment were determined by infrared method (IR, XP T 90-114 mod.). Results are gathered in Table 12 . The IR results were relatively well correlated with quantification by GC analysis on cyclohexane/acetone sediment extracts (data not shown).

The evolution of hydrocarbons concentrations measured by IR in 1995, 2000 and 2002 is given in Figure 7. The gradient of cuttings deposit, schematically separated into 4 zones, did not substantially evolve since 1995 , corresponding to the end of the first step of drilling:

- zone I $(<250 \mathrm{~m})$ : very affected;

- zone III (500 to $1000 \mathrm{~m}$ ): subnormal;

- zone IV (> $1000 \mathrm{~m}$ ): normal.

But, it is noteworthy that zone II (transition zone between 100 and $750 \mathrm{~m}$ ) strongly evolved between 2000 and 2002 (Fig. 7).

\section{Barium Content}

Barium is a good tracer for sediment contamination by drilling cuttings because it is a major component of drilling muds.

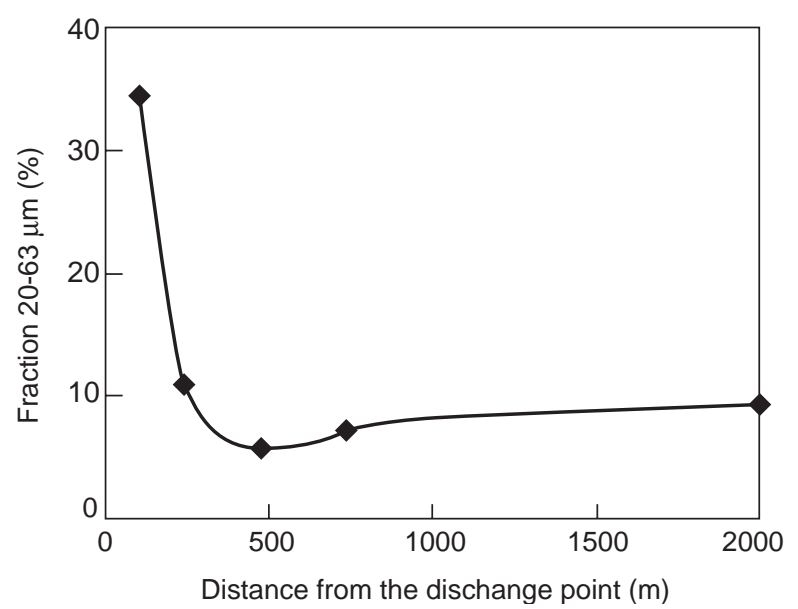

Figure 5

Spatial evolution of the relative amount of cuttings particles (20 to $63 \mu \mathrm{m}$ of size distribution) in the sediment (2002).

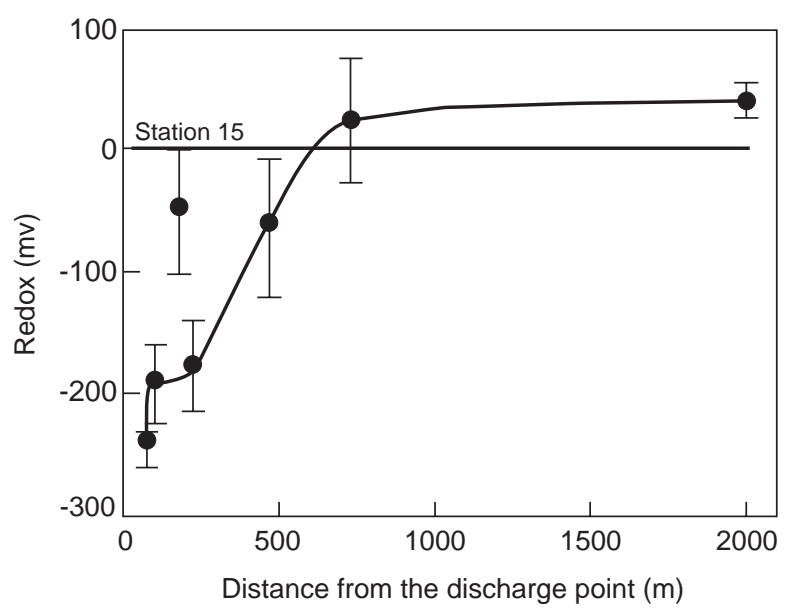

Figure 6

Spatial evolution of sediment Redox potential (2002). 
TABLE 12

Concentrations of total hydrocarbons in the sediment determined by IR (Infra-red)

\begin{tabular}{|c|c|c|c|}
\hline Station & Distance & $\begin{array}{c}\text { Hydrocarbons } \\
\text { concentrations } \\
\text { from IR (mg/dry kg) }\end{array}$ & Zones \\
\hline 2 & 2000 m South & $<10$ & $\begin{array}{l}\text { Zone IV } \\
>1000 \mathrm{~m} \\
\text { normal }\end{array}$ \\
\hline 16 & $730 \mathrm{~m}$ South & 21 & $\begin{array}{c}\text { Zone III } \\
\text { 500-1000 m } \\
\text { subnormal }\end{array}$ \\
\hline 3 & $470 \mathrm{~m}$ South & 90 & \multirow{2}{*}{$\begin{array}{l}\text { Zone II } \\
\text { 100-750 m } \\
\text { transition }\end{array}$} \\
\hline 4 & $230 \mathrm{~m}$ South & 1345 & \\
\hline 15 & $180 \mathrm{~m}$ East & 55 & \\
\hline 13 & $100 \mathrm{~m}$ South & 11400 & \multirow{2}{*}{$\begin{array}{c}\text { Zone I } \\
<250 \mathrm{~m} \\
\text { very affected }\end{array}$} \\
\hline 6 & $70 \mathrm{~m}$ West & 64305 & \\
\hline
\end{tabular}

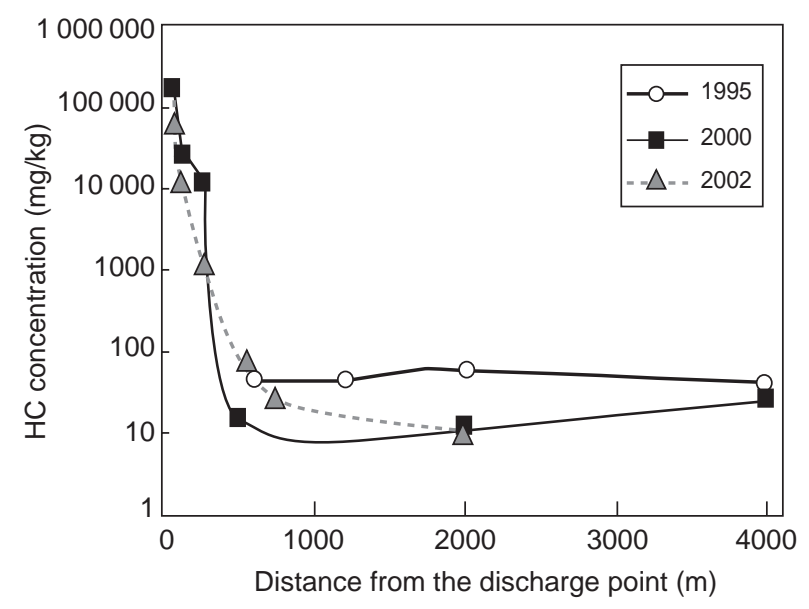

Figure 7

Spatial evolution of total hydrocarbons (HC) concentration in the sediment.

The concentration of barium in the different contaminated zones previously described is given in Table 13. The spatial evolution can be found in Figure 8a. It is noteworthy that from $250 \mathrm{~m}$ to $2000 \mathrm{~m}$, concentrations in barium slightly increased since 1995 , certainly due to spreading by currents. Signs of drilling mud contamination could be found up to $2000 \mathrm{~m}$, while no hydrocarbon was perceptible. Examination of hydrocarbon and barium concentrations in sediments, with regard to the distance from the discharge point seems to indicate a more pronounced decrease of hydrocarbons along the profile of deposit (Fig. 8b).
TABLE 13

Barium concentrations in the different contaminated zones

\begin{tabular}{c|c|c}
\hline Zone & Distance & $\begin{array}{c}\text { Barium concentrations } \\
\text { (mg/kg) }\end{array}$ \\
\hline $\begin{array}{c}\text { I } \\
\text { Very affected }\end{array}$ & $<250 \mathrm{~m}$ & 71800 to 142000 \\
\hline $\begin{array}{c}\text { II } \\
\text { Transition }\end{array}$ & 100 to $750 \mathrm{~m}$ & 3860 to 42300 \\
\hline $\begin{array}{c}\text { III } \\
\text { Subnormal }\end{array}$ & 500 to $1000 \mathrm{~m}$ & 1430 \\
\hline $\begin{array}{c}\text { IV } \\
\text { Normal }\end{array}$ & $>1000 \mathrm{~m}$ & 604 \\
\hline
\end{tabular}



Figure 8a

Spatial evolution of barium $(\mathrm{Ba})$ concentration in the sediment.



Figure 8b

Spatial evolution of the hydrocarbons/barium ratio in the sediment. 


\subsubsection{Toxicity Properties of Sediments}

\section{Lixiviation}

Results from the tests of lixiviation (total organic carbon and soluble hydrocarbons) as well as Microtox tests are gathered in Table 14. Lixiviation tests showed a release of a relatively great amount of organic matter, around $10 \mathrm{mg} / \mathrm{l}$. But, as it was previously reported in the case of cuttings, this organic matter release does not come from soluble hydrocarbons because the amount of soluble hydrocarbons does not exceed $104 \mu \mathrm{g} / \mathrm{l}$, in the case of the most contaminated station 6 .

\section{Toxicity}

Tests performed on Corophium arenarium (Table 15) showed a high toxicity of the sediment close to the discharge point $(<230 \mathrm{~m})$. From station $4(230 \mathrm{~m})$ and far away, the sediment toxicity declined clearly, associated with lower levels of hydrocarbon in sediments, in a range around $1 \mathrm{~g} / \mathrm{kg}$.

The test on the larval development of mollusks appeared also very sensitive and a high percentage of mortality could be observed as far as $470 \mathrm{~m}$ from the discharge point (Table 16). Nevertheless the significance of toxicity response around $30 \%$ of anomalies for the stations distant from the discharge point (blank station 2 and station 16) may be questioned.

From the Microtox test results (Table 14), sediments were not found toxic, except for the two closest samples 6 and 13 (respectively 70 and $100 \mathrm{~m}$ from the discharge point). For these two samples, a slight increase of inhibition could be observed when the amount of sediment in contact with water was multiplied by $10(250 \mathrm{~g} / \mathrm{l}$ instead of $25 \mathrm{~g} / \mathrm{l})$. The higher concentration tested $(250 \mathrm{~g} / \mathrm{l})$ led to the same range of tested concentrations in the case of the test on the larval development of mollusks (Table 16). In conclusion, the
Microtox test seems to be less sensitive than the test on mollusk.

For both tests in leachates the toxicity was likely due to other components than pure hydrocarbons, originated from additives in mud formulations, as previously mentioned with test on cuttings and muds. These latter have not to be confused with the high ground level of organic matter found in marine sediment (station 2).

\subsubsection{Benthos Composition}

In the laboratory, organisms were sorted out in order to gather them by sub-kingdom (crustaceans, annelids, etc.). The density of each species was determined and the specific richness (number of species) as well as the total density (total number of individuals $/ \mathrm{m}^{2}$ ) were calculated and compared with previous results.

\section{General Composition}

Considering all the samples from the seven stations in 2002, 151 species were identified. It is of the same order of magnitude as the whole richness obtained in 2000 on the samples from eleven stations in the same area (143 species). The repartition of species by sub-kingdom is the following:

- 114 annelids (75\% of the total population);

- 17 mollusks (11\%);

- 11 crustaceans $(7 \%)$;

- 3 nemerteans;

- 3 sipunculids;

- 1 cnidarian;

- 1 echinoderm;

- 1 nematode.

TABLE 14

Results from the test of lixiviation with sediments and Microtox test (toxicity on marine bacteria)

\begin{tabular}{|c|c|c|c|c|c|c|}
\hline \multirow[t]{2}{*}{ Station } & \multirow[t]{2}{*}{$\begin{array}{c}\text { Total carbon } \\
\text { in leachates }(\mathrm{mg} / \mathrm{l})\end{array}$} & \multirow[t]{2}{*}{$\begin{array}{l}\text { Total organic carbon } \\
\text { in leachates }(\mathrm{mg} / \mathrm{l})\end{array}$} & \multicolumn{2}{|c|}{$\begin{array}{c}\text { Hydrocarbons } \\
\text { in leachates }(\mu \mathrm{g} / \mathrm{l})\end{array}$} & \multirow{2}{*}{$\begin{array}{l}\text { Microtox } \\
\text { toxicity } \\
I_{\max }(\%)\end{array}$} & \multirow{2}{*}{$\begin{array}{c}\text { Microtox } \\
\text { toxicity } \\
\mathrm{EC}_{50}(\% \text { of dilution })\end{array}$} \\
\hline & & & BTEX & Soluble HC & & \\
\hline H base oil* & & & 0.5 & 63 & 37 & nd \\
\hline 2 & 21.5 & 11.1 & 2 & 13 & $<$ threshold & nd \\
\hline 16 & 19.2 & 8.5 & - & - & 20 & nd \\
\hline 3 & 24.6 & 12.1 & - & - & $<$ threshold & nd \\
\hline 4 & 20.6 & 7.4 & - & - & $<$ threshold & nd \\
\hline $13(25 \mathrm{~g} / \mathrm{l})$ & 25.4 & 5.1 & 1 & 17 & 28 & nd \\
\hline $13(250 \mathrm{~g} / \mathrm{l})$ & 122.7 & 28.1 & 0.2 & 86 & 37 & nd \\
\hline 15 & 21.4 & 10.0 & - & - & $<$ threshold & nd \\
\hline $6(25 \mathrm{~g} / 1)$ & 33.1 & 13.9 & 1 & 30 & 65 & 26.2 \\
\hline $6(250 \mathrm{~g} / \mathrm{l})$ & 220.3 & 57.0 & 0.3 & 104 & 88 & 5.0 \\
\hline
\end{tabular}

Lixiviation tests are carried out with $25 \mathrm{~g} / \mathrm{l}$ of dry sample. Some tests were also made with $250 \mathrm{~g} / \mathrm{l}$ of sample.

* with base oils, a contact was performed between oil and water.

$I_{\max }$ is the maximum inhibition of bacteria luminescence in presence of the maximum concentration in the test tube (leachate diluted at $50 \%$ ). EC ${ }_{50}$ is the percentage of dilution of the initial solution that leads to $50 \%$ of inhibition. Minimal threshold of inhibition: $20 \%$.

Soluble HC: BTEX are comprised in the total of the soluble fraction.

nd: not determined. 
TABLE 15

Toxicity test on Corophium arenarium (sediment reworker)

\begin{tabular}{r|c|c|c|c}
\hline \multicolumn{1}{c|}{ Station } & \multicolumn{2}{|c|}{$\mathrm{LC}_{50}(\%$ tested sediment $)$} & \multicolumn{2}{|c}{$\mathrm{LC}_{20}(\%$ tested sediment $)$} \\
\hline & $\mathrm{LC}_{50}$ & Confidence interval $95 \%$ & $\mathrm{LC}_{20}$ & Confidence interval $95 \%$ \\
\hline $2(2000 \mathrm{~m} \mathrm{~S})$ & $>100 \%^{*}$ & & $>100 \%^{*}$ & \\
$16(730 \mathrm{~m} \mathrm{~S})$ & $>100 \%^{*}$ & & $88.0 \%$ & $0.8 \%<\mathrm{LC}_{20}<6.1 \%$ \\
$3(470 \mathrm{~m} \mathrm{~S})$ & $>100 \%^{*}$ & & $80.0 \%$ & \\
$4(230 \mathrm{~m} \mathrm{~S})$ & $28.0 \%$ & $16 \%<\mathrm{LC}_{50}<76 \%$ & $3.2 \%$ & $11 \%<\mathrm{LC}_{20}<44 \%$ \\
$13(100 \mathrm{~m} \mathrm{~S})$ & $3.9 \%$ & $1.5 \%<\mathrm{LC}_{50}<7.2 \%$ & $<1 \%$ & \\
$15(180 \mathrm{~m} \mathrm{E})$ & $94.0 \%$ & & $26.0 \%$ & \\
$6(70 \mathrm{~m} \mathrm{~W})$ & $2.4 \%$ & $1.3 \%<\mathrm{LC}_{50}<3.5 \%$ & $<1 \%$ & \\
\hline
\end{tabular}

Project ISO/CD 16712 (27/06/2001), 10 days at $15^{\circ} \mathrm{C}$, dilutions in a "blank sediment".

*sediment tested without dilution in blank sediment.

TABLE 16

Toxicity test towards the larval development of mollusks (oysters)

\begin{tabular}{c|c|c|c}
\hline Station & $\begin{array}{c}\text { \% anomalies } \\
(100 \% \text { leachate })\end{array}$ & $\begin{array}{c}\text { \% anomalies } \\
\text { (50\% leachate })\end{array}$ \\
\hline $2(2000 \mathrm{~m} \mathrm{~S})$ & $38.6(3)$ & $35(2.6)$ & $22(2.6)$ \\
$16(730 \mathrm{~m} \mathrm{~S})$ & $32.8(6)$ & $31.4(2.3)$ & $22.8(3.1)$ \\
$3(470 \mathrm{~m} \mathrm{~S})$ & $73.4(5.1)$ & $60(4.2)$ & $32.6(2.4)$ \\
$4(230 \mathrm{~m} \mathrm{~S})$ & 100 & $83.6(3.4)$ & $25.6(2.1)$ \\
$13(100 \mathrm{~m} \mathrm{~S})$ & $55.2(2.8)$ & $31.4(2.9)$ & $28(2.1)$ \\
$15(180 \mathrm{~m} \mathrm{E})$ & $32(3.7)$ & $30(3.4)$ & $24.2(3.1)$ \\
$6(70 \mathrm{~m} \mathrm{~W})$ & 100 & 100 & $36(5.4)$ \\
\hline
\end{tabular}

Test on leachate ( $8 \mathrm{~h}, 60 \mathrm{~g}$ in $240 \mathrm{ml}$ sea water) clarified by decanting ( $8 \mathrm{~h}$ ) (His et al., 1999). Results are expressed as the \% of anomalies with 100,50 and $3 \%$ of leachate; values in brackets ( ): confidence interval $95 \%$; at $0 \%$ of leachate, the percentage of anomalies was around $10 \%$.

\section{General Structure}

Three groups can be underlined from the spatial evolution of the general structure of the settlement (see Fig. 9):

- At the blank station, the specific richness is of 56 species and the total density of $567 \mathrm{ind} . / \mathrm{m}^{2}$. The high values of diversity (5 bits) and equitability (86\%) show that no proliferation species exists and that the community is equilibrated and nondisturbed.

- For stations located at a distance less than $250 \mathrm{~m}$ from the discharge area, the settlement is poorer in species $(<29)$ but richer in individuals (up to 6743 ind. $/ \mathrm{m}^{2}$ point 13 at $100 \mathrm{~m}$ ). The species poverty is clearly due to the sediment toxicity. But the high total density is linked to the high level of organic matter (hydrocarbons) available for the less sensitive species.

- Above a distance between 250 and $500 \mathrm{~m}$ from the cuttings discharge point, the total density of the order of magnitude of 550 ind.$/ \mathrm{m}^{2}$, the specific richness of 50 species and the equitability of $85-90 \%$ are similar to the data obtained at the blank station (station 2).
The evolution of the settlement is clearly described in Figure 9:

- For a distance less than $100 \mathrm{~m}$ from the discharge area, specific richness and total density did not evolve since 2000. Sigambra sp. is the dominant species (2000 ind. $/ \mathrm{m}^{2}$, $94 \%$ of the whole population).

- In the zone 70-250 m, both variables (richness and density) increased since 2000, indicating that the sediment toxicity decreased. Sigambra sp. is still dominant (57\% of total individuals) but two other species succeeded in forming nonnegligible settlements: Ampharetidae sp. (1300 ind. $\left./ \mathrm{m}^{2}\right)$ and Capitella capitata $\left(740\right.$ ind. $\left./ \mathrm{m}^{2}\right)$.

- In the zone $100-500 \mathrm{~m}$, where a low specific richness ( 29 species) and a high total density $\left(2167\right.$ ind. $/ \mathrm{m}^{2}$ ) were observed in 2000 , the total number of species has become similar to that of the blank station (57) and the total density has increased. In this zone, the sediment toxicity disappeared and sensitive species can settle again. But the high level of organic matter tends to favor the development of opportunistic species such as Capitella capitata, 

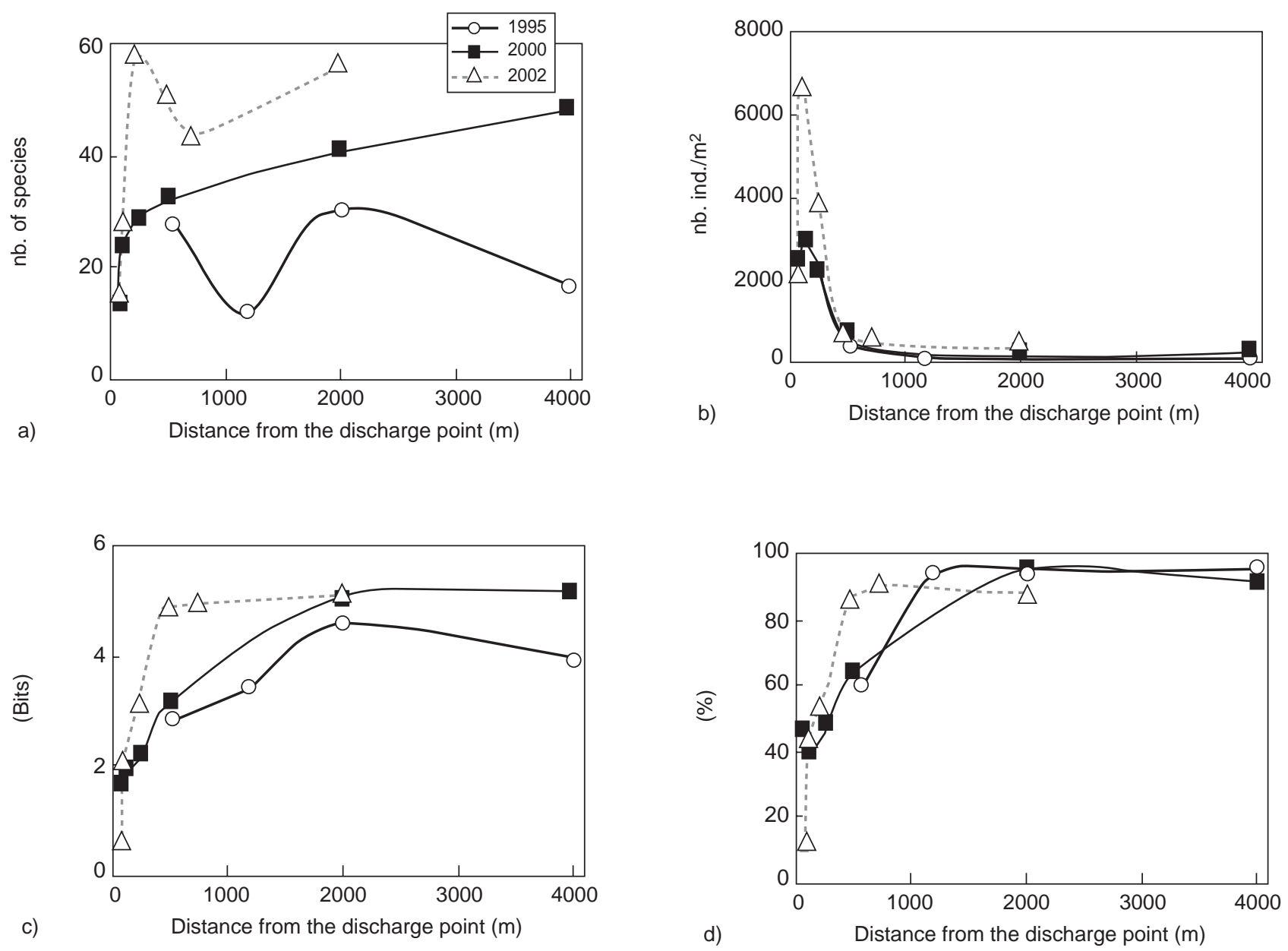

Figure 9

Spatial evolution of the general structure of the benthic settlement. a) specific richness (number of species); b) total density (number of individuals $/ \mathrm{m}^{2}$ ); c) diversity (Shannon-Wiener index expressed in bits); d) equitability (Pielou index expressed in \%).

Paramphinome cf. tryonix and Sigambra sp. (about 1000 ind./ $\mathrm{m}^{2}$ for each).

- Above a distance between 250 and $750 \mathrm{~m}$, data are available for the three years 1995, 2000 and 2002. The specific richness was low in 1995 and 2000 (28 and 32 species respectively). In 2002, it has become of the same order of magnitude as the blank station. The total density was low in 1995 (357 ind. $\left./ \mathrm{m}^{2}\right)$, but it increased in 2000 (603) and stayed constant in 2002 (560), of the same order of magnitude as in the blank station. In this zone, the high toxicity observed in 2000 disappeared in 2002 and sensitive species can settle again. No more proliferation of species is observed due to the relatively low level of organic matter in the sediment.

\section{Trophic Running of the Settlement}

Results from total biomass, trophic groups and trophic index are gathered in Figure 10.

\section{Total Biomass}

The total biomass in 2002 is particularly high on all the sampled stations (between 1.3 and $9.9 \mathrm{~g} / \mathrm{m}^{2}$ ) compared to 2000. It is noteworthy that the high value reported at the blank station 2 is essentially due to the crustacean Ampelisca sp. which exhibits a high biomass $\left(8.64 \mathrm{~g} / \mathrm{m}^{2}\right)$ but a very low density $\left(20\right.$ ind. $\left./ \mathrm{m}^{2}\right)$. But if the presence of this crustacean is not taken into account, the spatial evolution of the total biomass is similar to that of the total density. The maximum value of $9.9 \mathrm{~g} / \mathrm{m}^{2}$ is reached at station $13(100 \mathrm{~m})$ and corresponds to the highest total density $\left(6743\right.$ ind. $\left./ \mathrm{m}^{2}\right)$. This high value is related to the proliferation of Sigambra sp.

\section{Trophic Index}

The repartition of species according to their trophic group shows that the stations can be divided into two blocks:

- At the blank station 2 and at stations 3 and 16 (> $500 \mathrm{~m}$ ), groups 2 (flesh-feeders) and 3 (deposit-feeders) are largely 
dominant. The trophic index of about $60 \%$ confirms that the settlement is not disturbed, while this index indicated disturbance in 1995 for the zone 500-1500 m.

- For stations located at distances less than $250 \mathrm{~m}$, group 4 (anaerobic sediments-feeders) becomes dominant. This group comprises organisms that eat in hydrocarbons-rich sediments. In that case, the trophic index is less than $30 \%$ and confirms the high level of disturbance related to hydrocarbons inputs.



Trophic groups (2002)
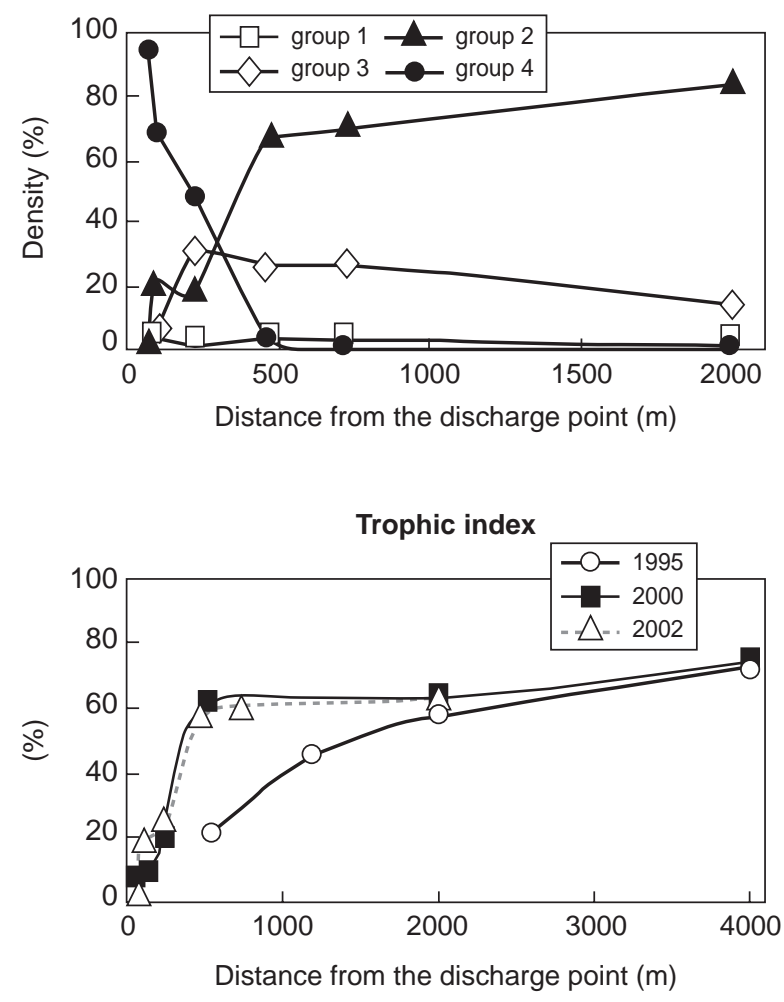

Figure 10

Spatial evolution of the trophic structure of the benthic settlement (total biomass in $\mathrm{g} / \mathrm{m}^{2}$, density of trophic groups in 2002 expressed in \% and trophic index expressed in \%).
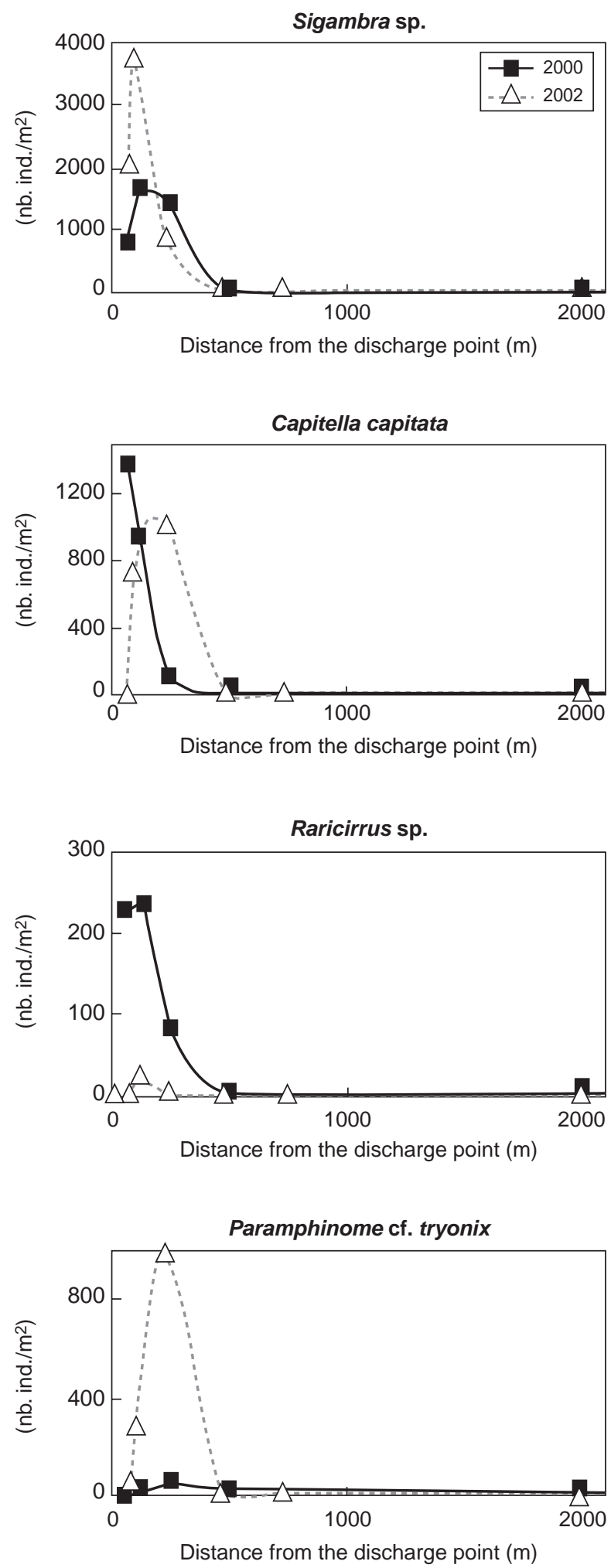

Figure 11

Spatial evolution of the density of dominant species in the area close to the discharge point (2000 and 2002), expressed in number of individuals $/ \mathrm{m}^{2}$ (Sigambra sp., Capitella capitata, Raricirrus sp. and Paramphinome cf. tryonix). 
Species Ecology (Fig. 11)

In 2000, the three dominant species in the area close to the discharge point were Sigambra sp. (Fig. 12), Capitella capitata (Fig. 13) and Raricirrus sp. (Fig. 14), from the trophic group number 4 (anaerobic sediments-feeders). Capitella capitata is a typical opportunistic species of this type of hydrocarbon-rich sediment, but it is noteworthy that the two other species are new ones, and were never observed nor described previously.

Since 2000, the number of Sigambra sp. strongly increased at the two stations close to the discharge point (70 and $100 \mathrm{~m}$ ), but it decreased at $230 \mathrm{~m}$. The adverse evolution is observed in the case of Capitella capitata. Raricirrus sp. is no more among dominant species in 2002. The third dominant species is Paramphinome cf. tryonix (Fig. 15), from the trophic group number 3 . This species eats large particles at

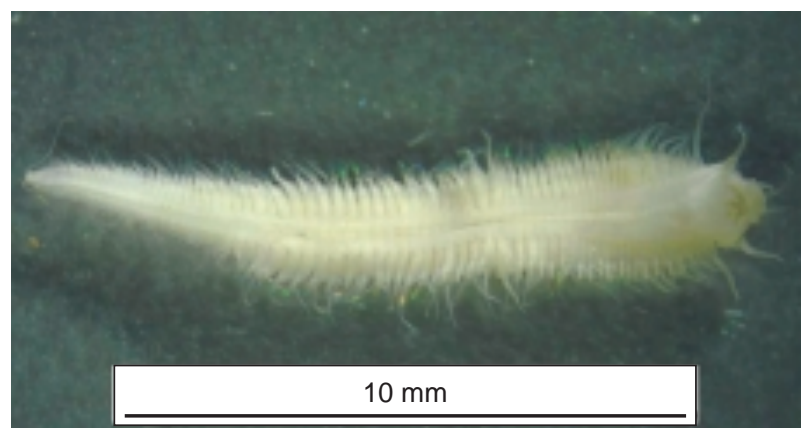

Figure 12

Sigambra sp.

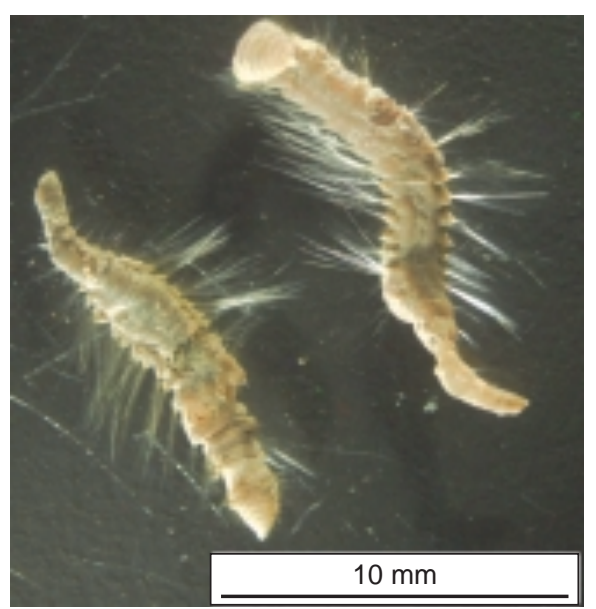

Figure 14

Raricirrus sp. the sediment surface, where the organic matter is poorly degraded. The results are presented in Figure 11.

Three other species reach their maximum number and are dominant at station 3 (470 $\mathrm{m}$ from the discharge point): Barantolla sp., Sigambra tentaculata and Neanthes cf. mossambica.

At station $16(730 \mathrm{~m})$, dominant species are Monticellina dorsobranchialis, Levinsenia sp.1 and Cossura cf. coasta.

Finally, the dominant species at the blank station 2 (2000 m) are Aricidea assimilis, Aricidea monicae and Prionospio ehlersi.

\subsubsection{Aerobic Biodegradation}

Only the sediments from stations 4, 13 and 6 were studied because other contained almost no hydrocarbons. Sediment

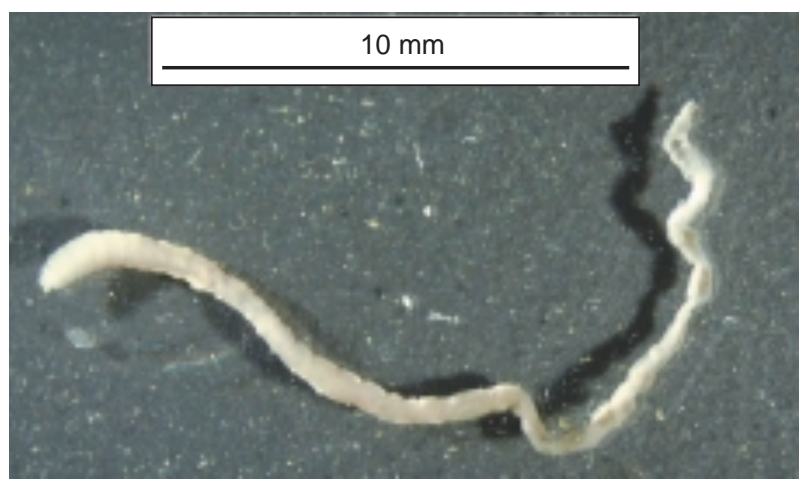

Figure 13

Capitella capitata.



Figure 15

Paramphinome cf. tryonix. 
from station 2 was used as a reference. The aerobic biodegradation tests have been conducted for 80 days. The indigenous flora was used as inoculum, and the starting $\mathrm{pH}$ was 8.2. The results are gathered in Table 17.

Oxygen consumption occurred with the sediment from the station 2, considered as "blank station": $118 \mathrm{mg} \mathrm{O}$ for $32 \mathrm{~g}$ of dry sediment. For the station $4(230 \mathrm{~m} \mathrm{~S})$, in presence of approximately the same amount of sediments ( $26 \mathrm{~g}$ ), the oxygen consumption was around 3 times higher (> $320 \mathrm{mg}$ ). With high hydrocarbons polluted sediments from station 13 $(100 \mathrm{~m} \mathrm{~S})$ and station $6(70 \mathrm{~m} \mathrm{~W})$ amounts of sediments put in the flasks were very small (between 2 and $3 \mathrm{~g}$ ).

In all cases, biodegradation of hydrocarbons was shown, around $70 \%$ for stations 4 and 6, and around $20-30 \%$ for station 13. This lower value is difficult to explain. Oxygen consumption seems to be well correlated with the amount of introduced hydrocarbons, with a good ratio "oxygen consumption/degraded hydrocarbons" for the more polluted sediment (station 6).

\section{DISCUSSION AND CONCLUSION}

The first phase of this project was dedicated to the ecotoxicological (toxicity and biodegradability) evaluation of different types of cuttings.

The results from the lixiviation tests on native cuttings showed that large quantities of organic compounds (dissolved or pseudo-emulsified organic compounds) were released in the leachates, whatever the drilling fluids origins (diesel oil, X oil, H oil and glycol solution), the largest amount being obtained with glycol based cuttings. In all cases, concentrations of soluble hydrocarbons were two or three orders of magnitude below TOC concentrations.

The toxicity study demonstrated a quite weak toxicity of cuttings when measured with OSPAR tests and the two additional tests. No Microtox inhibition was found for the three different base oils tested (diesel oil, $\mathrm{X}$ oil, $\mathrm{H}$ oil). On the other hand a weak toxicity against the marine bacteria was found with dearomatized oil-based cuttings ( $\mathrm{X}$ and $\mathrm{H}$ oils) while diesel oil cuttings showed no detectable toxicity. This result can lead to the conclusion that components present in the respective mud formulations, different from soluble hydrocarbons, may be responsible for the toxicity response towards the marine bacteria.

The test on larvae of mollusks was as sensitive as the OSPAR test on copepods. But it is noteworthy that with the mollusk test, a high mortality was found with WBM cuttings (certainly due to the high toxicity of glycol). Finally responses with test on fish larvae are rather difficult to interpret.

It is interesting to note that, although experimental conditions were not identical, all the tests operated on leachates gave a positive response, for cuttings/water contacts around $24 \mathrm{~g} / \mathrm{l}$.

More interesting, since it uses a benthic species, the test on the amphipod Corophium arenarium showed clearly a toxic effect, whatever the base oils.

Finally, all cuttings were found aerobically biodegradable. The anaerobic tests confirmed that among all the base oils tested (paraffinic, diesel oil and esters), only esters were biodegradable in strictly anaerobic conditions.

From these results, it was decided to select the toxicity tests on Corophium arenarium (sediment reworker) and on larvae of mollusks as well as the Microtox test for the continuation of the project. The quality and amount of information given by the lixiviation and biodegradation tests were found very useful for the following studies, and it was decided to apply them to the sediments sampled from the field test, in addition to classical measurements.

In field experiments, barium was an interesting tracer since it is a major component of drilling fluids, and it is neither biodegradable nor bioavailable. The barium concentrations were very high at the bottom of the platform and then decreased progressively. At distances between 250 and $500 \mathrm{~m}$, levels of barium and hydrocarbons slightly increased (2002), compared to initial values (1995). This showed a re-distribution of the contaminated sediments from the bottom of the platform. The barium concentration profile did not coincide completely with the profile of hydrocarbon

TABLE 17

Aerobic biodegradation tests for sediments ( 80 days)

\begin{tabular}{|c|c|c|c|c|c|c|c|c|c|c|c|c|}
\hline & \multicolumn{12}{|c|}{ Stations } \\
\hline & \multicolumn{4}{|c|}{4} & \multicolumn{4}{|c|}{6} & \multicolumn{4}{|c|}{13} \\
\hline Sediments (g) & \multicolumn{4}{|c|}{26} & \multicolumn{4}{|c|}{2 to 3} & \multicolumn{4}{|c|}{2 to 3} \\
\hline Initial hydrocarbons (mg) & 119 & 122 & 120 & 120 & 468 & 448 & 482 & 482 & 82 & 89 & 90 & 87 \\
\hline Degraded hydrocarbons (mg) & 84 & 88 & 85 & 92 & 356 & 330 & 359 & 384 & 25 & 18 & 15 & 29 \\
\hline Degraded HC (\%) & 71 & 72 & 71 & 76 & $76^{* / 5} 9^{* *}$ & $74 * / 55^{* *}$ & $75^{*} / 57^{* *}$ & $80 * / 66^{* *}$ & 30 & 20 & 17 & 33 \\
\hline $\mathrm{O}_{2}$ consumption $(\mathrm{mg})$ & 330 & 320 & 394 & 365 & 535 & 555 & 476 & 573 & 126 & 84 & nd & 138 \\
\hline $\mathrm{O}_{2}$ cons./degraded $\mathrm{HC}$ & 3.9 & 3.6 & 4.6 & 4.0 & $1.9-1.5$ & $2.2-1.7$ & $1.7-1.3$ & $1.8-1.5$ & 5.1 & 4.8 & nd & 4.8 \\
\hline
\end{tabular}

* extraction efficiency of $59+/-6 \%$ in the abiotics. No correction of residual hydrocarbons.

** extraction efficiency of $59+/-6 \%$ in the abiotics. Residual hydrocarbon corrected (increase of residual values). 
concentrations in the sediments. Indeed, the analyses of hydrocarbon concentrations in the sediment showed a more pronounced decrease of hydrocarbon levels along the profile. These data seem to attest that a biodegradation process is associated with natural dispersion along the profile of settling.

These observations are confirmed by the results from both the tests of biodegradability and toxicity performed on sediments. Between 100 and $500 \mathrm{~m}$, a rapid restoration towards normal values can be observed. Hence, hydrocarbons can be degraded at the seafloor, even in very contaminated zones, as demonstrated by laboratory biodegradation experiments conducted with the indigenous microflora. This biodegradation process was due to the high surface of exchange available between the sediment and the water interface, and also to the biological activity of benthic organisms, which sink galleries and put anaerobic sediments to the surface. Although the number of species was low, the number of individuals was quite high, especially in the highly contaminated zone (zone $100-500 \mathrm{~m}$ ) and their role must be essential.

The behavior of the benthic community in this cutting discharge site was similar to previous observations around platforms: the number of species was quite low (about 15) in the central zone at the bottom of the platform in 2000 as in 2002. Total density was high, due to the proliferation of species. At larger distances from the discharge point, the number of species progressively increased. Few species were associated with proliferating species, but as distance increased, proliferating species disappeared while more diverse species appeared. A detailed study of this evolution allowed to understand the recolonization process. From a general point of view, opportunistic species, which were the most resistant, colonized first the polluted sediment and thus prepared the medium for other less resistant species. In the present case, the initial pollution by cuttings showed its own toxicity that was confirmed by the different tests carried out in the framework of this study. This toxicity was as much high as cuttings were recent.

Some species like Lindaspio sebastiani were only present in the initial phases of cuttings discharge in the more contaminated zones. This species was therefore found very abundant in 1995 at the bottom of the platform $\left(220 \mathrm{ind} . / \mathrm{m}^{2}\right)$, but at a low quantity in the same zone in $2000\left(30 \mathrm{ind} . / \mathrm{m}^{2}\right)$ and totally absent in the samples of 2002. Its diminution when the contamination decreased seems to indicate that its presence depends on some chemical reactions, as it is the case of organisms subjugated to cold dripping in deep waters. Hence, larvae of such organisms in the water column could have found favorable conditions for their development at the bottom of the platform. Their temporary growth in the sediment favored the colonization by new species. Then, these species initially present disappeared with the rapid evolution of physical chemical conditions at the surface of cuttings. It is noteworthy that a value of 220 ind. $/ \mathrm{m}^{2}$ can not be considered as a proliferation. It is also possible that this species can not multiply on site.

Sigambra sp. is another species subjugated to the most polluted zones. However, its behavior strongly differs from Lindaspio sebastiani. While this latter was present in small quantity and rapidly disappeared, Sigambra sp. showed a true proliferation that amplified with time. This species, absent in 1995, was characterized by high densities in 2000 (1600 ind./ $\mathrm{m}^{2}$ ). Two years after (2002), its density reached $3800 \mathrm{ind} . / \mathrm{m}^{2}$. This species probably took advantage of the abundant organic matter that came from the degradation of hydrocarbons, after the first phase of acute toxicity. Arrived on the site by the same process as for Lindaspio sebastiani (metamorphosis of pelagic larvae) when subsequently the sediment becomes more favorable, Sigambra sp. first cohabits with the precedent species and then eliminates it due to its greater ability to reproduce. The large population of Sigambra sp. as well as the presence of every classes of size clearly shows that the species reproduces on site. Hence, the bioturbation process initiated by Lindaspio sebastiani can go on and is amplified by the intense activity of the population of Sigambra sp. It is noteworthy that other species have the same type of behavior while less abundant (1000 ind. $/ \mathrm{m}^{2}$ in 2002): it is the case of Paramphinome cf. tryonix for which a significant increase of density was observed between 2000 and 2002.

Finally, Raricirrus sp. seems to occupy an intermediate place between the two previous species. Quite large densities were observed in 2000 (230 ind. $\left./ \mathrm{m}^{2}\right)$, but it tends to disappear in $2002\left(23 \mathrm{ind} . / \mathrm{m}^{2}\right)$. Consequently, in this zone of maximal pollution, different species follow each other and contribute to the amelioration of the physical chemical quality of the sediment in order to receive more demanding species.

During the drilling operations on the studied site, about $10000 \mathrm{~m}^{3}$ of cuttings were discharged. The first survey performed in 1995, just after the first phase of drilling, showed that the cutting pile was rapidly recolonized by benthic organisms. Even in extreme situations (almost pure cuttings), some rare species did settle at the surface of the discharge core. The extension of benthic communities, toxicity results and hydrocarbons contents measurements enabled us to conclude on the occurrence of three different areas, very different from an ecological point of view:

- between 0 and $250 \mathrm{~m}$, where the impact is high. The toxicity is strong, hydrocarbons abundant and fauna is dominated by some characteristic species;

- between 250 and $750 \mathrm{~m}$, an area of significant impact. The fauna is more diversified, less abundant, the toxicity is weak, and hydrocarbons are weakly present;

- beyond $750 \mathrm{~m}$, area without impact. The fauna is normal, there is no toxicity, and hydrocarbons are absent. 
In order to foresee the probable evolution of the cutting pile after several years, it is interesting to note that ecological successions with time are in fact similar to those that can develop as a function of a spatial gradient. In the zone between 250 and $1000 \mathrm{~m}$, several species have a clearly define place. Their succession is essentially shown in space, some species growing preferably close to the platform, and others growing far away. While less spectacular than successions observed with time at the bottom of the platform, these spatial successions appear nevertheless as quite remarkable. Some species preferably prosper at $400 \mathrm{~m}$ from the discharge point (Barantolla sp., Sigambra tentaculata or Neanthes cf. mossambica), other prosper at $700 \mathrm{~m}$ (Levinsenia sp.1). Finally, some very sensitive species are only observed on the reference zone at $2000 \mathrm{~m}$ (Aridicea assimilis and Aridicea monicae). It is noteworthy that between $250 \mathrm{~m}$ and $1000 \mathrm{~m}$, hydrocarbons concentrations as well as toxicity of sediment are very low. Nevertheless, biocoenosis seem sensitive to the "distance effect". This observation clearly proves the extreme sensitivity of these organisms that can be used as bioindicators of environmental modifications.

To conclude, it is noteworthy that structural variables like specific richness, density or diversity index confirm previous observations made on several offshore drilling sites. But a new information is given by the detailed study of species successions in space and time. The different species that follow each other contribute to the restoration of the sediment. One of the most remarkable point is the arrival, from the beginning (first phase of drilling) of species that are able to grow in a very aggressive environment. The larvae of these species probably come from deeper zones (cold dripping). These particular species contribute to the sediment restoration and then make way to more classical opportunistic species that take advantage of the abundant organic matter offered by hydrocarbons.

\section{ACKNOWLEDGEMENTS}

This work was granted from CEPM (France). We thank all contributors from Total, IFP, Créocéan and Ifremer to this study and especially Total-Congo for their contribution to the field experiment and R. Delesmont (Institut Pasteur Lille) for toxicity tests.

\section{REFERENCES}

Blanchet, D., Audibert, A. and Argillier, J.F. (1998) Anaerobic biodegradability of oil base fluid for invert emulsion drilling fluids. Paper IADC/SPE 39386, presented at 1998 IADC/SPE Drilling Conference, Dallas, Texas, 3-6 march.

Bouchez, M., Blanchet, D., Besnainou, B., Leveau, J.Y. and Vandecasteele, J.P. (1997) Kinetic studies of biodegradation of insoluble compounds by continuous determination of oxygen consumption. J. Appl. Bacteriol., 82, 310-316.
British Petroleum (2000) Deep-Sea Biodiversity and Oil and Gas Exploration and Production, BP Green Operations Initiative, September.

Candler, J.E., Hoskin, S., Churan, S., Cui Wei Lai, M. and Freeman, M. (1995) Seafloor monitoring for synthetic-based mud discharged in the western gulf of Mexico. SPE 29694, Proceedings of the SPE/EPA Exploration and Production Environmental Conference, Houston, Tx, 27-29 March.

Daan, R. and Mulder, M. (1996) On the short-term and long-term impact of drilling activities in the Dutch sector of the North Sea. ICES Journal of Marine Science, 53, 1036-1044.

Daan, R., Booij, K., Mulder M. and van Weerlee, EM. (1996) Environmental effects of a discharge of drill cuttings contaminated with ester-based drilling muds in the North Sea. Environmental Toxicology and Chemistry, 15, 10, 1709-1722.

Davies, J., Bedborough, D., Blackman, R.A.A., Addy, J., Appelbee, J., Grogan, W., Parker, J.G. and Whithehead, A. (1988) The Environmental Effects of Oil Based Mud Drilling in the North Sea, prepared by the UKOOA/Government Working Group Set Up to Establish and Monitor the Environmental Impacts of Offshore Oil Development in the UK.

Davies, J., Bedborough, D., Blackman, R.A.A., Addy, J., Appelbee, J., Grogan, W., Parker J.G. and Whithehead, A. (1989) The Environmental Effects of Oil Based Mud Drilling in the North Sea. Drilling Wastes, FR. Engelhardt, JP. Ray and AH. Gillam Eds, Elsevier Applied Science, London.

Doherty, F.G. (2001) A review of Microtox registered toxicity test system for assessing the toxicity of sediments and soils. Water Quality Research Journal of Canada, 36, 3, 475-518.

E\&P Forum (1996) E\&P Forum Joint Study - The physical and biological effects of processed oily drill cuttings. E\&P Forum Report No. 2.61/202, April.

Fechelm, R.G., Gallaway, B.J. and Farmer, J.M. (1999) Deepwater sampling at a synthetic drilling mud discharge site on the outer continental shelf, Northern Gulf of Mexico. SPE Paper 52744, presented at 1999 SPE/EPA, Austin, Tx, Feb. 28-March 3.

His, E., Beiras, R. and Seaman, M.N.L. (1999) The assessment of marine pollution - Bioassays with bivalve embryos and larvae. Advances in Marine Biology, 37, 1-178.

Jensen, T., Palerud, R., Olsgard, F. and Bakke, S.M. (1999) Dispersion and effects of synthetic drilling fluids in the environment. Technical Report No. 99-3507 to the Ministry of Oil and Energy.

Kingston, P.F. (1992) Impact of offshore oil production installations on the benthos of the North Sea. ICES J. Mar. Sci., 49, 45-53.

Lees, D.C. and Houghton, J.P., (1980) Effects of drilling fluids on benthic communities at the lower Cook Inlet COST Well. Proceedings of Research on Environmental Fate and Effects of drilling Fluids and Cuttings, Lake Buena Vista, Florida, January, 21-24 1980, II, 309-350.

Munro, P.D., Moffat, C.F., Couper, L., Brown, N.A., Croce, B. and Stagg, R.M. (1997) Degradation of synthetic mud base fluids in a solid phase test system. Fisheries Research Services Report No. 1/97, Scottish Office Agriculture, Environment and Fisheries Department, Marine Laboratory, Aberdeen, January.

Neff, J.M., McKelvie, S. and Ayers, R.C. Jr. (2000) Environmental Impacts of Synthetic Based Drilling Fluids, Report prepared for MMS by R. Ayers and Associates, Inc., August 2000, US Department of Interior, Minerals management Service, Gulf of Mexico, OCS Region, New Orleans, OCS Study MMS 2000-064.

(http://www.gomr.mms.gov./homepg/regulate/environ/00-0064.pdf)

OGP (2003), Environmental aspects of the use and disposal of non aqueous drilling fluids associated with offshore oil and gas operations. Report No. 342, May. 
Oliver, G.A. and Fisher, S.J. (1999) The persistence and effects of non-water based drilling fluids on Australia's Northwest shelf: progress findings from three seabed surveys. APPEA Journal, 647-662.

Olsgard, F. and Gray, J.S. (1995) A comprehensive analysis of the effects of offshore oil and gas exploration and production on the benthic communities of the Norwegian continental shelf. Marine Ecology Progress Series, 122, 277-306.

OSPAR (1995a) Part A: A sediment bioassay using an amphipod Corophium sp. In: PARCOM Protocols on Methods for the Testing of Chemicals Used in the Offshore Industry.

OSPAR (1995b) Part B: Protocol for a fish acute toxicity test. In: PARCOM Protocols on Methods for the Testing of Chemicals Used in the Offshore Industry.

OSPAR (2000) Decision 2000/2 on a Harmonized Mandatory Control System for the Use and Discharge of Offshore Chemicals.

Pawliszyn, J. (1997) Solid Phase Microextraction - Theory and Practice, Wiley-VCH, New York.

Smith, J.P., Ayers, R.C Jr. and Tait, R.D. (1997) Perspectives from research on the environmental effects of ocean discharges of drilling muds and cuttings. Third International Conference on the
Development of the Russian Arctic Offshore, St Petersburg, Russia, 23-26 september.

Stronkhorst, J., Schipper, C., Brils, J., Dubbeldam, M., Postma, J., van de Hoeven N. (2003) Using marine bioassays to clarify the toxicity of Dutch harbor sediments. Environ. Toxicol. Chem., 22, 7, 1535-1547.

Terrens, G.W., Gwyther, D., Keough, M.J., Tait, R.D., (1998), Environmental assessment of synthetic based drilling mud discharges to the Bass Strait Australia. Proceedings of SPE International Conference on Health, Safety and Environment in Oil and Gas Exploration and Production, No. 46622, Caracas, Venezuela, 7-10 June.

UKOOA (2001) Drill Cuttings Initiative Final Report, December.

USEPA (2001) Effluents Limitations Guidelines and New Source Performance Standards for the Oil and Gas Extraction Point Source Category; OMB Approval under the Paperwork Reduction Act: Technical Amendment, 66 Federal Register 14, January.

Word, J.Q. (1990) The infaunal trophic index, a functional approach to benthic community analyses. PhD Thesis, University of Washington.

Final manuscript received in Septembre 2004 or distributed for profit or commercial advantage and that copies bear this notice and the full citation on the first page. Copyrights for components of this work owned by others than IFP must be honored. Abstracting with credit is permitted. To copy otherwise, to republish, to post on servers, or to redistribute to lists, requires prior specific permission and/or a fee. Request permission from Documentation, Institut français du pétrole, fax. +33147527078 , or revueogst@ifp.fr. 